\title{
Cell biological aspects of the vasopressin type-2 receptor and aquaporin 2 water channel in nephrogenic diabetes insipidus
}

Joris H. Robben, Nine V. A. M. Knoers and Peter M. T. Deen

Am J Physiol Renal Physiol 291:F257-F270, 2006. doi:10.1152/ajprenal.00491.2005

You might find this additional info useful...

This article cites 169 articles, 82 of which can be accessed free at:

http://ajprenal.physiology.org/content/291/2/F257.full.html\#ref-list-1

This article has been cited by 21 other HighWire hosted articles, the first 5 are:

Vasopressin increases S261 phosphorylation in AQP2-P262L, a mutant in recessive nephrogenic diabetes insipidus

Christiane Trimpert, Dennis T.M. van den Berg, Robert A. Fenton, Enno Klussmann and Peter

M.T. Deen

Nephrol. Dial. Transplant., July 9, 2012; .

[Abstract] [Full Text] [PDF]

V2 Vasopressin Receptor (V2R) Mutations in Partial Nephrogenic Diabetes Insipidus

Highlight Protean Agonism of V2R Antagonists

Kazuhiro Takahashi, Noriko Makita, Katsunori Manaka, Masataka Hisano, Yuko Akioka,

Kenichiro Miura, Noriyuki Takubo, Atsuko Iida, Norishi Ueda, Makiko Hashimoto, Toshiro

Fujita, Takashi Igarashi, Takashi Sekine and Taroh Iiri

J. Biol. Chem., January 13, 2012; 287 (3): 2099-2106.

[Abstract] [Full Text] [PDF]

Protein localization in disease and therapy

Mien-Chie Hung and Wolfgang Link

J Cell Sci, October 15, 2011; 124 (20): 3381-3392.

[Abstract] [Full Text] [PDF]

The physiological implication of novel proteins in systemic osmoregulation

Anne P. Sinke and Peter M. T. Deen

FASEB J, October , 2011; 25 (10): 3279-3289.

[Abstract] [Full Text] [PDF]

Counteracting vasopressin-mediated water reabsorption by ATP, dopamine, and phorbol esters: mechanisms of action

Michelle Boone, Marleen L. A. Kortenoeven, Joris H. Robben, Grazia Tamma and Peter M. T.

Deen

Am J Physiol Renal Physiol, March , 2011; 300 (3): F761-F771.

[Abstract] [Full Text] [PDF]

Updated information and services including high resolution figures, can be found at:

http://ajprenal.physiology.org/content/291/2/F257.full.html

Additional material and information about AJP - Renal Physiology can be found at: http://www.the-aps.org/publications/ajprenal

This information is current as of July 11, 2012.

AJP - Renal Physiology publishes original manuscripts on a broad range of subjects relating to the kidney, urinary tract, and their respective cells and vasculature, as well as to the control of body fluid volume and composition. It is published 12 times a year (monthly) by the American Physiological Society, 9650 Rockville Pike, Bethesda MD 20814-3991. Copyright @ 2006 by the

American Physiological Society. ISSN: 1931-857X, ESSN: 1522-1466. Visit our website at http://www.the-aps.org/. 


\title{
Cell biological aspects of the vasopressin type- 2 receptor and aquaporin 2 water channel in nephrogenic diabetes insipidus
}

\author{
Joris H. Robben, Nine V. A. M. Knoers, and Peter M. T. Deen \\ Department of Physiology, Nijmegen Centre for Molecular Life Sciences and Human \\ Genetics, Radboud University Nijmegen Medical Centre, Nijmegen, The Netherlands
}

\begin{abstract}
Robben, Joris H., Nine V. A. M. Knoers, and Peter M. T. Deen. Cell biological aspects of the vasopressin type-2 receptor and aquaporin 2 water channel in nephrogenic diabetes insipidus. Am J Physiol Renal Physiol 291: F257-F270, 2006; doi:10.1152/ajprenal.00491.2005.-In the renal collecting duct, water reabsorption is regulated by the antidiuretic hormone vasopressin (AVP). Binding of this hormone to the vasopressin V2 receptor (V2R) leads to insertion of aquaporin-2 (AQP2) water channels in the apical membrane, thereby allowing water reabsorption from the pro-urine to the interstitium. The disorder nephrogenic diabetes insipidus (NDI) is characterized by the kidney's inability to concentrate pro-urine in response to AVP, which is mostly acquired due to electrolyte disturbances or lithium therapy. Alternatively, NDI is inherited in an X-linked or autosomal fashion due to mutations in the genes encoding V2R or AQP2, respectively. This review describes the current knowledge of the cell biological causes of NDI and how these defects may explain the patients' phenotypes. Also, the increased understanding of these cellular defects in NDI has opened exciting initiatives in the development of novel therapies for NDI, which are extensively discussed in this review.
\end{abstract}

osmoregulation; protein trafficking; genetic disorder; collecting duct; lithium; pharmacological chaperones

MAINTAINING BODY WATER HOMEOSTASIS is of vital importance for proper functioning of most physiological processes in the human body. Under normal conditions, the glomerular filtration rate (GFR) of the two kidneys amounts $180 \mathrm{l} /$ day. Of this huge volume, also called the pro-urine, $\sim 90 \%$ is reabsorbed in the proximal tubule and descending limb of Henle's loop, which is a constitutive process. According to need, the remaining fluid can be reabsorbed in the collecting duct. This process is tightly regulated by an elegant system, which allows the body to adapt to periods of water load or water restriction. The key hormone in this process is the antidiuretic hormone arginine-vasopressin (AVP), which is secreted by the posterior pituitary in response to states of hypovolemia or hypernatremia (94). In healthy individuals, secreted AVP will be transported by the blood to the kidney, where it can bind to vasopressin V2 receptors (V2R), which are mainly present on the basolateral (interstitial) side of the principal collecting duct cells (112). The activated V2R will induce an increase of intracellular cAMP levels via the stimulatory Gs protein and adenylate cyclase, which will eventually lead to activation of protein kinase A and to phosphorylation of aquaporin-2 (AQP2) water channels $(45,68)$. Phosphorylation of at least three of four monomers of an AQP2 tetramer is then sufficient to redistribute AQP2 homotetramers from storage vesicles to the apical membrane, rendering this membrane permeable to water (63, 157). Following an osmotic gradient of sodium and urea, water will then pass the apical membrane via AQP2 and will leave

Address for reprint requests and other correspondence: P. M. T. Deen, 286-Dept. Physiology, RUNMC, Nijmegen/NCMLS, PO Box 9101, 6500 HB Nijmegen, The Netherlands (e-mail: p.deen@ncmls.ru.nl). the cells on the basolateral side via AQP3 and AQP4 (57, 69), thereby compensating for the hypovolemic or hypernatremic state of the body. This process is summarized in Fig. 1. When sufficient water is reabsorbed to restore homeostasis, serum vasopressin levels will decrease (94), and AQP2 will be internalized from the apical membrane, resulting in decreased water reabsorption. Katsura et al. (67) showed that this AVP-regulated recycling of AQP2 can occur at least six times with the same repertoire of AQP2 molecules. In addition to its direct regulation of water transport, AVP also increases sodium transport in the collecting duct via the epithelial sodium channel $(\mathrm{ENaC})(8,38)$ and urea transport via the UT-A1 transporter (141)

Malfunctioning of water reabsorption can lead to a variety of disorders, which can be of central or renal origin. Centrally, in the syndrome of inappropriate secretion of antidiuretic hormone, AVP levels are abnormally increased, leading to excessive renal water reabsorption, which might result in lifethreatening hyponatremia (118). The most common causes of the syndrome of inappropriate secretion of antidiuretic hormone are neoplasia, like nonmalignant lung carcinoma, neurological disorders, congestive heart failure, liver cirrhosis, preeclampsia, and drugs like thiazide diuretics or selective serotonin reuptake inhibitor antidepressants. These effects have recently been reviewed in more detail and will not be discussed here $(11,110)$.

At the other extreme is diabetes insipidus (DI), in which patients are unable to concentrate their urine, resulting in polyuria and, consequently, polydipsia. With central DI, humans lack the ability to produce functional AVP and therefore to actively concentrate their urine. Sometimes, this is due to 
Fig. 1. Regulation of aquaporin-2 (AQP2)mediated water transport by vasopressin (AVP). Shown is a nephron with a magnified principal cell. In this cell, the vasopressin V2 receptor (V2R), stimulatory GTP binding protein (Gos), adenylate cyclise (AC), ATP, cAMP, and phosphorylated proteins (O-P) are indicated. For details, see the text.

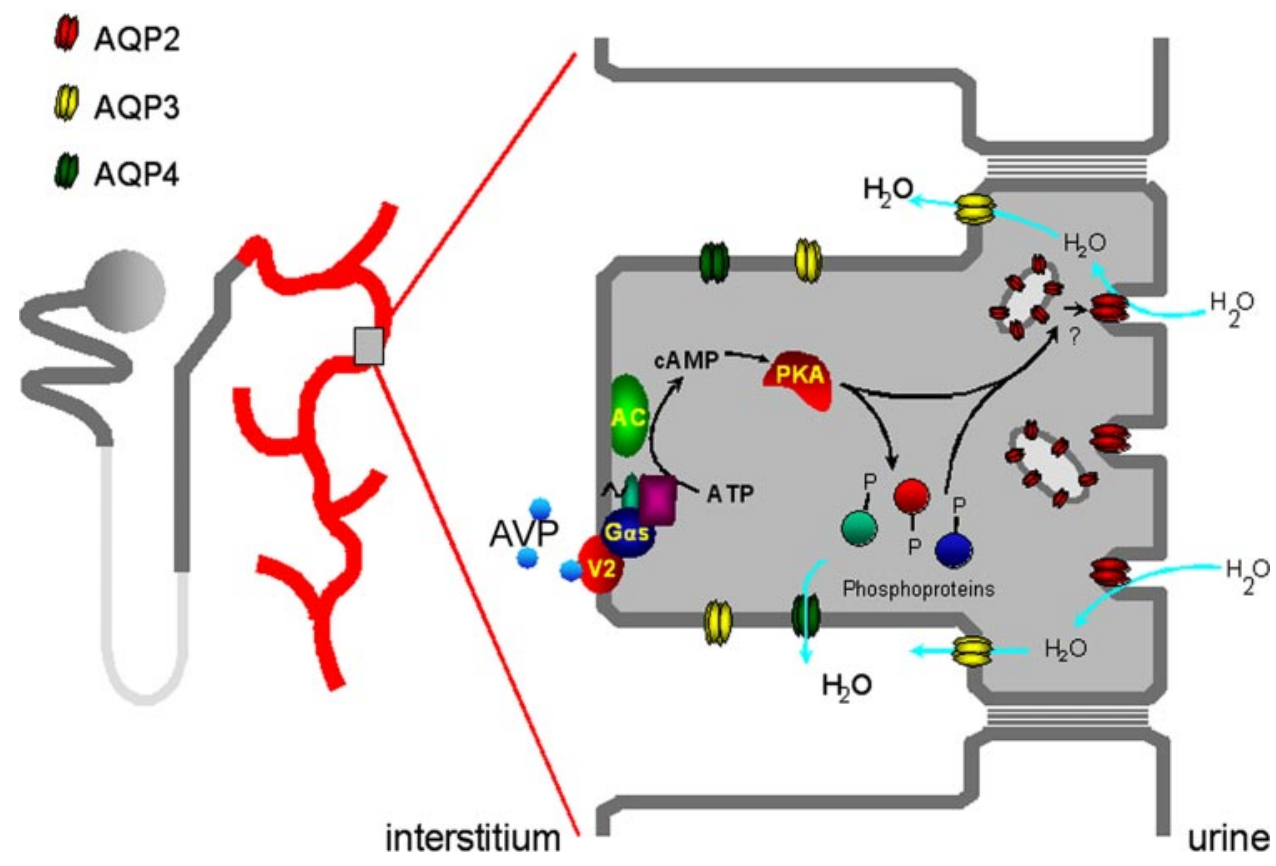

AVP gene mutations $(3,6,44,48,128)$. Administration of the synthetic AVP homolog 1-desamino-8-D-arginine vasopressin (DDAVP), however, is usually able to drastically decrease urine output in these patients. A well-studied disturbance of water homeostasis, and the main topic of this review, is nephrogenic diabetes insipidus (NDI). In this disorder, patients are unable to concentrate their urine, despite increased serum AVP levels. This review focuses on the molecular causes underlying NDI and how this information may aid in identifying novel therapies for this disorder.

\section{ACQUIRED NDI}

Most commonly, NDI is acquired due to several conditions, which can be divided into three different groups.

\section{Electrolyte Disturbances}

Two clinically important electrolyte abnormalities, hypokalemia and hypercalcemia, lead to polyuria and urinary concentration effects. Hypokalemia is found in up to $21 \%$ of hospitalized patients, develops in $\sim 50 \%$ of patients with secondary hyperaldosteronism or using furosemide/thiazide diuretics, and may lead to the development of polyuria, NDI, and reduced AQP2 expression $(89,171)$. Indeed, in potassium-deprived rats, a $70 \%$ reduction in expression and a redistribution from the plasma membrane to intracellular vesicles were observed for AQP2 compared with control rats (89). This effect has been attributed to a reduced pituitary AVP release, blunted renal response to $\mathrm{AVP}$, intrarenal $\mathrm{PGE}_{2}$ production, and impaired AVP-sensitive adenylate cyclase, but might also be due to a reduced interstitial tonicity, as hypokalemia-induced NDI coincides with a severe downregulation of major renal sodium and urea transporters $(39,60)$, and an elevated tonicity increases AQP2 expression in vitro $(50,66,151)$.

Hypercalcemia, which is mostly due to primary hyperparathyroidism and malignancies such as lytic bone disease or humoral hypercalcemia, causes NDI, leading to severe dehy- dration (123). Studies using excess vitamin D or parathyroid hormone rat models reveal that hypercalcemia-induced NDI is accompanied by a reduced GFR and interstitial tonicity and an increased urinary and fractional sodium excretion (166). The reduced expression of type $2 \mathrm{Na}-\mathrm{P}_{\mathrm{i}}$ cotransporter, type-3 $\mathrm{Na}$ / $\mathrm{H}$-exchanger, Na-K-ATPase, and $\mathrm{Na}-\mathrm{K}-2 \mathrm{Cl}$ cotransporter in hypercalcemia-induced NDI likely contributes to the increased urinary sodium excretion and decreased urine concentration (166). Moreover, hypercalcemia-induced NDI coincides with diminished total and apical membrane expression of AQP2, at normal AQP2 mRNA levels, whereas AQP3 expression is also reduced $(37,165)$. The effects on AQP2 are ascribed to activation of the apical calcium-sensing receptor (CaSR) by hypercalciuria, which is thought to subsequently induce the internalization of AQP2 as a means of reducing antidiuresis and preventing renal stone formation $(142,154)$. Although the underlying molecular mechanism for the effect on AQP2 is still poorly understood, Sands et al. (142) identified in an elegant study a signaling pathway linking renal water and calcium metabolism, as in purified apical endosomes from inner medullary collecting duct (IMCD) cells; they found besides AQP2

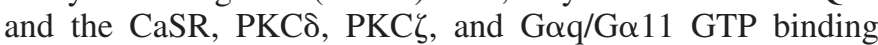
proteins, the latter two of which had been reported earlier to interact with the CaSR. In line with these findings, Procino et al. (125) found later that CaSR-mediated downregulation and internalization of AQP2 in transfected renal cells by extracellular calcium coincide with a strong activation of PKCs, reduced forskolin-induced cAMP levels, and increased F-actin content. The role of decreased cAMP levels in hypercalcemiainduced NDI is further corroborated by the finding of Wang et al. (165) that treatment of such rats with cAMP-phosphodiesterase inhibitors prevents polyuria and reduced AQP2 expression.

\section{Urinary Tract Obstruction}

Urinary tract obstruction is a serious clinical condition, which in children is usually due to congenital abnormalities of 
the kidneys and urinary tract, whereas in adults is mostly caused by stones, enlargement of the prostate, and urinary tract neoplasms. After removal of the obstruction, a marked polyuria develops, which is restored to normal in time, although a somewhat decreased maximum concentrating ability persist for a long time (43). Although the mechanism remains poorly understood, several studies in rats, especially by the Frøkiær team $(41,81,82,122)$, have shown that obstruction-induced NDI is likely due to reduced expression of major renal sodiumtransporting proteins [NHE3, Na-K-ATPase, NaPi-2, NKCC1, and the sodium-chloride cotransporter (NCC)] and AQP1-4, all along the nephron (for a recent review, see Ref. 42). A recent study shed some light on the underlying mechanism, as Norregaard et al. (113) found that the reduction in AQP2, NHE3, and NKCC1 expression in the inner medulla, but not in other parts of the kidney, coincided with increased cyclooxygenase-2 (COX-2) expression and prostaglandin release from interstitial cells in rats with bilateral ureteral obstructions. Also, treatment with the COX-2 inhibitor parecoxib prevented downregulation of these transporters. It remains to be determined whether COX-2 inhibitors can shorten the period of NDI after the obstruction is removed.

\section{Lithium-Induced NDI}

Lithium, which is the drug of choice for treating bipolar disorders, is successful in reducing both manic and depressive symptoms in $70-80 \%$ of patients and reduces the excessive mortality rate observed in this illness (27). Unfortunately, development of NDI is a common side effect. Because $0.1 \%$ of humans are on lithium therapy and severe forms of this side effect present in $\sim 10-20 \%$ of patients, lithium-NDI is the most common acquired form of NDI (150). Chronic lithium treatment decreases the GFR (13) and, considering the narrow therapeutic index of lithium (0.6-1.2 meq/l), toxicity resulting from severe dehydration is a problem of significant clinical importance in lithium-NDI. Moreover, lithium-NDI is associated with hyperchloremic metabolic acidosis, renal tubular acidosis $(35,70,107,132)$, and increased natriuresis. Rat studies revealed that lithium-NDI coincides with decreased total AQP2 expression and a reduced expression of AQP2 in the apical membrane (88). Further rat studies revealed that the effect depends on the period of lithium treatment, as short-term (10-14 days) treatment downregulates AQP2 expression without affecting renal morphology, whereas long-term (i.e., 4 wk or longer) treatment also causes an increase in intercalated cells at the expense of principal cells $(25,70,80)$. The lithiuminduced natriuresis is suggested to be due to the reduced expression in some, but not all, renal segments, of several salt-transporting proteins, such as NCC, the $\alpha$ - and $\beta$-subunits of $\mathrm{ENaC}$, and the Na-K-ATPase $(80,108,109,131)$. The mechanism underlying the metabolic and distal tubular acidosis in lithium-NDI is poorly understood. Surprisingly, with long term-lithium treatment, it coincides with strongly increased expression levels of apical $\mathrm{H}^{+}$-renal ATPase, which cannot be explained by the increased number of intercalating cells, and altered expression of several other acid-base transporters (70).

Recent studies shed some light on the mechanisms underlying the reduced AQP2 levels in lithium-NDI. As indicated for electrolyte and obstructive NDI, the reduced AQP2 expression in lithium-NDI might be due to a reduced interstitial osmolality (131). Also, Rao et al. (126) arrived at the suggestion that increased $\mathrm{PGE}_{2}$ expression, which counteracts AVP-induced AQP2 total and plasma membrane expression, might explain AQP2 reduction in lithium-NDI (126). In an elegant study, these authors found that polyuria in COX-1-deficient mice treated with lithium for 4 days resulted in increased COX-2 expression and $\mathrm{PGE}_{2}$ release from interstitial cells and that polyuria and $\mathrm{PGE}_{2}$ release were blunted on inhibition of COX-2 expression. Similar data were observed in Brattleboro rats, indicating that the observed effects were independent from AVP. In contrast, however, lithium-NDI due to a 4-wk lithium treatment in rats coincided with reduced $\mathrm{COX}-1$ and COX-2 levels in the inner medulla, which were strongly increased with dehydration (75). At present, an explanation for these differences is lacking.

Analysis of direct effects of lithium on AQP2 expression have been hampered by the availability of a cell line endogenously expressing AQP2 in response to AVP. Recently, such a cell line was generated (49). We found that these murine cortical collecting duct (mpkCCD) cells are well suited for studying the effects of lithium on AQP2 in more detail, as treatment with clinically relevant concentrations of lithium resulted in a marked reduction in, and reduced plasma membrane expression of, AQP2 (83). Surprisingly, lithium did not affect AVP-induced cAMP generation, phosphorylation or stability of AQP2, or the phosphorylation of the AQP2 transcription factor, the cAMP responsive element binding protein (CREB). Instead, it caused a decrease in AQP2 mRNA levels, indicated that lithium reduces $\mathrm{AQP} 2$ gene transcription or mRNA stability. Although further data need to be obtained, an effect of lithium on AQP2 gene transcription is in line with our findings that lithium does not affect AQP2 protein levels in transfected Madin-Darby canine kidney (MDCK) cells in which AQP2 expression is directed from a non-AQP2-related promoter (Shaw S, Li Y, et al., unpublished observations). Our data seem to contradict earlier studies in which it was found that lithium treatment of rats interfered with adenylate cyclase activity, cAMP generation, and PKA activation in isolated renal tubules (26). However, whereas these rats were chronically treated with lithium and, therefore, the observed effects might be due to the changed cellular constitution of their renal collecting ducts (25) and/or reduced sensitivity of the renal collecting duct due to increased circulating AVP levels in lithium-NDI rats (83), our data are obtained with only a 2-day (cells) or short-term (rats) lithium treatment, periods at which a changed cellular constitution of cell layer and renal tubules was not observed (25).

\section{CONGENITAL NDI}

Congenital NDI can be divided into X-linked and autosomal recessive and dominant NDI. Here, we will discuss the genes and proteins involved in these forms of congenital NDI in humans and those only found in animals.

\section{$X$-Linked NDI}

The X-linked and most prominent form of congenital NDI is caused by loss-of-function mutations in the AVPR2 gene, encoding the V2R $(19,85)$, which is a member of the family of $\mathrm{G}$ protein-coupled receptors (GPCR; Fig. 2). Over 180 AVPR2 
Fig. 2. Proposed topology of the human V2R. The V2R has 7 transmembrane domains with its $\mathrm{NH}_{2}$ terminus extracellular and its $\mathrm{COOH}$ terminus intracellular. The transmembrane domains are connected by 3 extracellular (ECL1-3) and intracellular (ICL1-3) loops. The N-glycosylation site (at $\mathrm{N} 22$ ) in its $\mathrm{NH}_{2}$ terminus and the palmitoylated cysteines (C141-142) in its $\mathrm{COOH}$ terminus are indicted. Bright amino acids are conserved among V1R, V2R, and V3R.

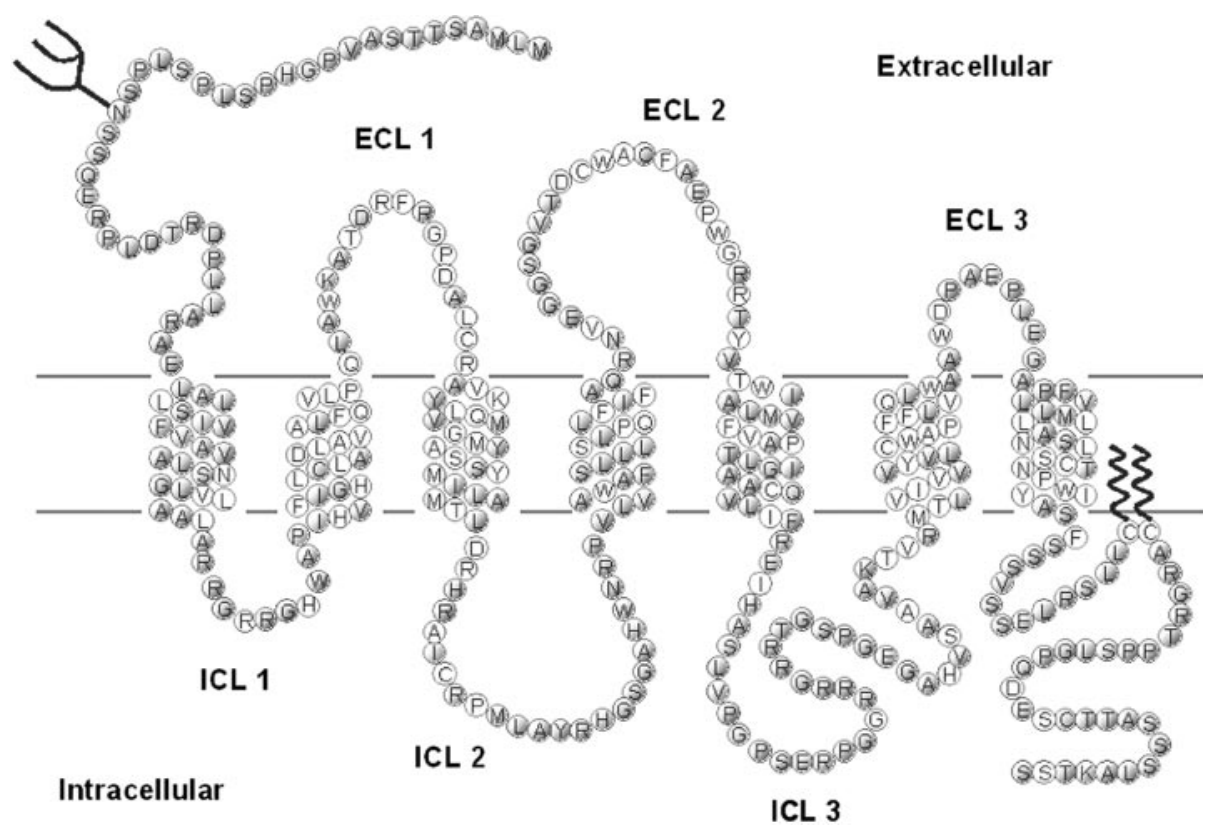

gene mutations have been described (http://www.medicine. mcgill.ca/nephros), of which many result in severe interference with receptor signaling, thus making the principal cells of the collecting duct insensitive to AVP. The molecular mechanism underlying this insensitivity, however, differs among mutants. As upcoming pharmacological treatments for NDI likely depend on the underlying mechanism, we recently divided GPCR mutations into general and particular V2R mutations in five different classes according to their cellular fate $(30,129)$ (Fig. $3 A$ and Table 1).

Class I comprises all mutations that lead to improperly processed or unstable mRNA, like promoter alterations, exon skipping, or aberrant splicing. This class also holds frame-shift and non-sense mutations, which result in truncated proteins like V2R-Q119X, -W293X, and -R337X.
Class II mutations are missense or insertion/deletion of one or more nucleotide triplets, resulting in fully translated proteins. Due to the mutation, however, mutant receptors are misfolded and retained in the endoplasmic reticulum (ER), as the ER is the organelle that has the cellular quality control over proper folding and maturation of synthesized proteins. Misfolded proteins are subsequently mostly targeted for proteasomal degradation (40). Intracellular entrapment of missense V2R mutants and their rapid degradation likely represent the most important cause for NDI, as $>50 \%$ of the mutations in V2R are missense mutations and cellular expression revealed that most of these result in ER-retained proteins. The extent of ER retention, however, may differ among mutants and may represent differences in their folding state. Hermosilla et al. (51) recently reported that of eight V2R mutants that are
A

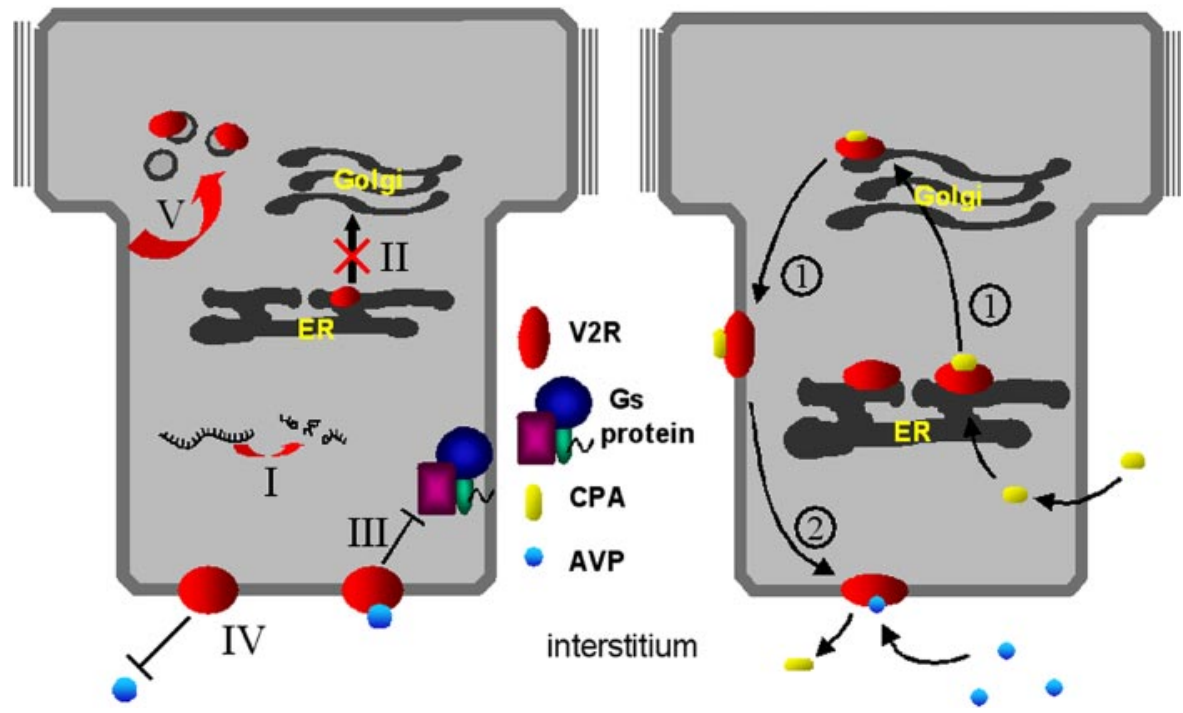

Fig. 3. Cellular fate of V2R mutants in nephrogenic diabetes insipidus (NDI) and their rescue. $A$ : V2R mutation classes in NDI. Shown is a schematic view of a collecting duct cell. The different mutation classes are indicated by roman numerals. Mutation can lead to mRNA instability, splicing errors, and nonsense mutations ( $I$ ); endoplasmic reticulum (ER) retention (II); impaired Gs coupling (III); impaired AVP binding $(I V)$; and mislocation in the cell $(V)$. See the text for details. $B$ : pharmacological chaperones rescue class II V2R mutants. Class II V2R mutants are retained in the ER, but on binding of cell-permeable antagonists (CPA), stabilization of their structure allows them to exit the ER, mature in the Golgi, and subsequently translocate to the plasma membrane (1). At the membrane, displacement of the CPA by AVP will allow restoration of the cAMP cascade (2).

A urine B 
Table 1. V2R mutations involved in NDI

\begin{tabular}{|c|c|c|c|c|c|c|c|}
\hline Nucleotide & Amino Acid & Referred/Analysis & Functionality & $\begin{array}{l}\text { Conserved } \\
\text { (Location) }\end{array}$ & Class & Diagnosis & Treatment \\
\hline $492 \mathrm{~T}>\mathrm{C}$ & L44P & $(5 ; 72 ; 99 ; 116 ; 117 ; 129)$ & $\mathrm{F}$ & $\mathrm{Y}(\mathrm{tmd} 1)$ & II & $1 \mathrm{wk}$ & $\mathrm{dD}: \mathrm{NR}$ \\
\hline $488 \mathrm{~T}>\mathrm{A}$ & $\mathrm{I} 46 \mathrm{~K}$ & $(120)$ & $\mathrm{F}$ & $\mathrm{N}(\mathrm{tmd} 1)$ & II & $5 \mathrm{yr}$ & ndD:NR \\
\hline $548 \mathrm{~T}>\mathrm{C}$ & $\mathrm{L} 62 \mathrm{P}$ & $(5 ; 72)$ & $?$ & $\mathrm{Y}(\mathrm{tmd} 1)$ & II? & $21,53 \mathrm{mo}$ & $\mathrm{dD}: \mathrm{NR}$ \\
\hline $545-553 \mathrm{del}$ & $\Delta 62-64$ & $(18 ; 129)$ & $\mathrm{G}$ & $\mathrm{N}(\mathrm{tmd} 1)$ & II & $?$ & $?$ \\
\hline $574 \mathrm{G}>\mathrm{A}$ & W71X & (17) & & $\mathrm{N}(\mathrm{ICL} 1)$ & $\mathrm{I}$ & $?$ & $\mathrm{dD}: \mathrm{NR}$ \\
\hline $612 \mathrm{C}>\mathrm{A}$ & A84D & (3) & A & $\mathrm{N}(\mathrm{tmd} 2)$ & II & $?$ & $?$ \\
\hline $614 \mathrm{G}>\mathrm{A}$ & D85N & $(61 ; 120 ; 130)$ & $\mathrm{F}$ & $\mathrm{Y}(\mathrm{tmd} 2)$ & III & $32 \mathrm{mo}$ & $\mathrm{nD}, \mathrm{dD}$-deh.: $>400$ \\
\hline $623 \mathrm{G}>\mathrm{A}$ & V88M & $(72 ; 160 ; 163)$ & $?$ & $\mathrm{Y}(\mathrm{tmd} 2)$ & II & $16 \mathrm{mo}$ & ndD:NR; deh.: > 500, PS 158 \\
\hline $692 \mathrm{~T}>\mathrm{C}$ & W99R & (3) & A & Y (ECL1) & $\begin{array}{l}\text { II, } \\
\text { IV }\end{array}$ & $?$ & $?$ \\
\hline $671 \mathrm{C}>\mathrm{T}$ & $\mathrm{R} 104 \mathrm{C}$ & $(55 ; 96)$ & $\mathrm{F}$ & Y (ECL1) & II & 8 days & ndD:NR:dD:>300;thiaz., DDAVP \\
\hline $674 \mathrm{~T}>\mathrm{G}$ & F105V & $(120)$ & A & Y (ECL1) & IV & $?$ & 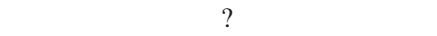 \\
\hline $698 \mathrm{C}>\mathrm{T}$ & R113W & $(72 ; 136)$ & $\mathrm{F}$ & Y (tmd3) & $\begin{array}{l}\text { II, } \\
\text { IV }\end{array}$ & $?$ & dD-deh.:NR \\
\hline $749 \mathrm{~A}>\mathrm{T}$ & $\mathrm{I} 130 \mathrm{~F}$ & $(120 ; 129)$ & $\mathrm{F}$ & $\mathrm{N}(\mathrm{tmd} 3)$ & II & $1 \mathrm{mo}$ & ndD:NR \\
\hline $771 \mathrm{G}>\mathrm{A}$ & $\mathrm{R} 137 \mathrm{H}$ & $(9 ; 17 ; 92 ; 61 ; 133 ; 134 ; 138 ; 139 ; 144)$ & G & Y (ICL2) & $\begin{array}{c}\text { II, } \\
\text { III, } \\
\text { V }\end{array}$ & $?$ & dD-deh.:NR (292):dD:>400 PO(282) \\
\hline $860 \mathrm{~T}>\mathrm{A}$ & S167T & $(115 ; 117 ; 129 ; 172)$ & $\mathrm{F}$ & $\mathrm{N}(\mathrm{tmd} 4)$ & II & $1 \mathrm{mo}$ & $\mathrm{dD}: \mathrm{NR}$ \\
\hline $861 \mathrm{C}>\mathrm{T}$ & S167L & $(72 ; 115 ; 117 ; 129 ; 170 ; 172)$ & A & $\mathrm{N}(\mathrm{tmd} 4)$ & II & $2 \mathrm{wk}, 8 \mathrm{mo}$ & $\mathrm{ndD}, \mathrm{dD}: \mathrm{NR}$ \\
\hline $902 \mathrm{C}>\mathrm{T}$ & $\mathrm{R} 181 \mathrm{C}$ & $(18 ; 72 ; 129 ; 144 ; 146)$ & A & $\mathrm{N}(\mathrm{tmd} 4)$ & IV & $6 \mathrm{mo}$ & ndD:NR \\
\hline $914 \mathrm{G}>\mathrm{T}$ & $\mathrm{G} 185 \mathrm{C}$ & $(145 ; 158 ; 160)$ & A & N (ECL3) & IV & $7,9,108,128,204 \mathrm{mo}$ & dD-deh.: >300 \\
\hline $963 \mathrm{G}>\mathrm{A}$ & G201D & $(129 ; 136)$ & $\mathrm{F}$ & Y (ECL3) & $\begin{array}{l}\text { II, } \\
\text { IV }\end{array}$ & $?$ & dD-deh.: $>400$ \\
\hline $965 \mathrm{C}>\mathrm{T}$ & R202C & $(3 ; 6 ; 145 ; 155 ; 169)$ & A & N (ECL3) & IV & $18 \mathrm{mo}$ & $?$ \\
\hline $966-967$ del & $\Delta \mathrm{R} 202$ & (2) & A & N (ECL3) & IV & $?$ & $\mathrm{dD}: \mathrm{NR}$ \\
\hline $972 \mathrm{C}>\mathrm{A}$ & $\mathrm{T} 204 \mathrm{~N}$ & $(72 ; 124 ; 129 ; 161)$ & A & N (ECL3) & II & $15 \mathrm{mo}$ & $\mathrm{dD}: \mathrm{NR} ; \mathrm{dD}:>200$ \\
\hline $975 \mathrm{~A}>\mathrm{G}$ & Y205C & $(51 ; 124 ; 158 ; 160 ; 163)$ & A & Y (ECL3) & II & $2 \mathrm{wk}, 2.5 \mathrm{mo}$ & $\mathrm{dD}: \mathrm{NR}$ \\
\hline $978 \mathrm{~T}>\mathrm{A}$ & V206D & $(72 ; 124 ; 128)$ & A & $\mathrm{N}$ (tmd5) & II & $?$ & $\mathrm{dD}: \mathrm{NR}$ \\
\hline $1431 \mathrm{C}>\mathrm{T}$ & P322S & $(2 ; 163)$ & $\mathrm{F}$ & $\mathrm{Y}(\mathrm{tmd} 7)$ & $\begin{array}{l}\text { III, } \\
\text { IV }\end{array}$ & $10 \mathrm{mo}, 8 \mathrm{yr}$ & dD-deh.: $>400$ \\
\hline $1476 \mathrm{C}>\mathrm{T}$ & R337X & $(18 ; 24 ; 51 ; 72 ; 100 ; 114 ; 137 ; 153 ; 189)$ & A & N (C-tail) & $\mathrm{I}$ & $4 \mathrm{mo}$ & dD:NR, deh>300, PS 189 \\
\hline
\end{tabular}

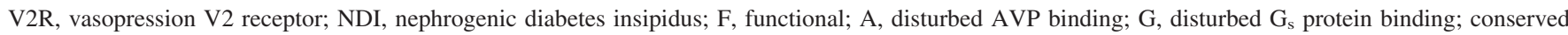

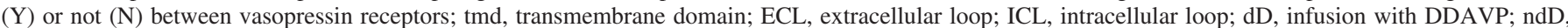

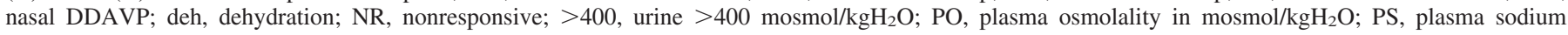
$\left(\mathrm{mosmol} / \mathrm{kgH}_{2} \mathrm{O}\right)$.

retained, only three were strictly kept in the ER, whereas the five other mutants were transported to the ER-Golgi intermediate compartment, followed by retrograde transport to the ER.

Class III comprises similar mutations to class II, but the resulting mutants are not considered misfolded by the ER and can continue their itinerary to the plasma membrane. However, these mutations disturb binding of the stimulatory Gs protein, leading to reduced activation of adenylate cyclase and thus formation of cAMP.

Class IV mutations also result in full-length receptors expressed at the cell surface, but here the mutation interferes with, or reduces, AVP binding. These mutations especially involve residues thought to be in or close to the AVP binding pocket, of which V2R- $\Delta \mathrm{R} 202$ is a clear example (2).

Finally, class $\mathrm{V}$ mutations allow normal protein synthesis and maturation, but they cause misrouting to different organelles in the cell. The NDI R137H mutation, located in the well-conserved DRY/H motif of GPCRs, is a member of this class, as V2R-R137H is constitutively internalized from the plasma membrane and therefore only briefly available to bind AVP $(10,15)$.

Sometimes, mutants do not exert a full phenotype of a particular class and then often also show features of another class. For example, some V2R missense mutants are partially ER retained (class II) but are also partially expressed in the plasma membrane, where they might show a reduced $\mathrm{G}$ protein coupling (class III) or AVP binding (class IV). Indeed, V2RR113W, -G201D, and -T204N stably expressed in polarized MDCK cells are partially ER retained, whereas a considerable fraction is expressed in the basolateral membrane (129). As such, this provides an explanation for the observed small antidiuretic response to high doses of DDAVP in NDI patients harboring such mutations (124) (Table 1). For a full interpretation of these increased urine osmolalities with DDAVP, blood osmolalities and sodium levels are also important but have only been reported for a few patients (Table 1).

\section{Autosomal Recessive NDI}

Approximately $10 \%$ of the patients diagnosed for NDI have mutations in the AQP2 gene, which is mapped to chromosome $12 q 13(34,140)$. Of these, $>90 \%$ suffer from recessive NDI. Most, but not all $(28,34)$, of these patients are of consanguineous lineage and have inherited two identical mutant AQP2 alleles. In total, 34 AQP2 mutations have been described, of which 27 are involved in recessive NDI (Table 2). Of this group, $78 \%$ comprise missense mutations. On expression of the encoded mutants in cell systems, nearly all mutants were misfolded and trapped in the ER (class II), followed by rapid proteasomal degradation $(31,33,84,90,92,104,152)$. Con- 
Table 2. AQP2 mutations involved in NDI

\begin{tabular}{|c|c|c|c|c|c|c|c|c|c|}
\hline Nucleotide & Amino Acid & $\begin{array}{l}\text { Homozygous/ } \\
\text { Heterozygous }\end{array}$ & $\begin{array}{c}\text { Recessive/ } \\
\text { Dominant }\end{array}$ & Referred/Analysis & Functionality & $\begin{array}{l}\text { Conserved } \\
\text { (Location) }\end{array}$ & Class & Diagnosis & Treatment \\
\hline $64 \mathrm{C}>\mathrm{G}$ & L22V & he 3 & $\mathrm{r}$ & $(23) /(152)$ & $\mathrm{P},(60 \%)$ & $\mathrm{N}(\operatorname{tmd} 1)$ & II & (64) & $\mathrm{dD}$ \\
\hline $83 \mathrm{~T}>\mathrm{C}$ & L28P & ho & $\mathrm{r}$ & $(90) /(90)$ & & $\mathrm{N}(\operatorname{tmd} 1)$ & II & $1 \mathrm{mo}$ & $\mathrm{dD}: \mathrm{NR}$ \\
\hline $170 \mathrm{~A}>\mathrm{C}$ & Q57P & he5 & $\mathrm{r}$ & $(84) /(84)$ & $\mathrm{NF}$ & $\mathrm{N}(\operatorname{tmd} 2)$ & II & ? & $\mathrm{dD}: \mathrm{NR}$ \\
\hline $190 \mathrm{G}>\mathrm{A}$ & G64R & ho & $\mathrm{r}$ & $(162) /(31 ; 92 ; 162)$ & P $(20 \%)$ & Y (b-loop) & II & $1 \mathrm{mo}$ & $\mathrm{dD}: \mathrm{NR}$ \\
\hline $293 \mathrm{~A}>\mathrm{G}$ & N68S & ho & $\mathrm{r}$ & $(104) /(92)$ & $\mathrm{NF}$ & Y (b-loop) & II & $1.6 \mathrm{mo}$ & e:dD-deh.:>300; dD:NR \\
\hline $299 \mathrm{G}>\mathrm{T}$ & G100V & he 5 & $\mathrm{r}$ & $(84) /(84)$ & NF & $\mathrm{N}$ (tmd 3) & II & $?$ & $\mathrm{dD}: \mathrm{NR}$ \\
\hline 369delC & Frameshift & ho & $\mathrm{r}$ & $(162) /(162)$ & & & I & $?$ & ? \\
\hline $374 \mathrm{C}>\mathrm{T}$ & $\mathrm{T} 125 \mathrm{M}$ & ho, he 8 & $\mathrm{r}$ & $(46 ; 77) /(46 ; 80)$ & $\mathrm{P},(25 \%)$ & $\mathrm{N}$ (c-loop) & II & $?$ & $?$ \\
\hline $377 \mathrm{C}>\mathrm{T}$ & $\mathrm{T} 126 \mathrm{M}$ & ho & $\mathrm{r}$ & $(92) /(46 ; 82 ; 104)$ & P $(20 \%)$ & $\mathrm{N}$ (c-loop) & II & $6 \mathrm{mo}$ & dD-deh.:NR \\
\hline $439 \mathrm{G}>\mathrm{A}$ & A147T & ho & $\mathrm{r}$ & $(104) /(92 ; 104)$ & $\mathrm{F}$ & Y (d-loop) & II & $3 \mathrm{mo}$ & dD-deh.:NR \\
\hline $450 \mathrm{~T}>\mathrm{A}$ & D150E & he7 & $\mathrm{r}$ & $(47) /(47)$ & NF & Y (d-loop) & II & $?$ & $?$ \\
\hline $928 \mathrm{G}>\mathrm{A}$ & A190T & he 2 & $\mathrm{r}$ & $(28 ; 77) /(28 ; 77)$ & $\mathrm{NF}$ & $N(e-l o o p)$ & II & $?$ & dD:NR \\
\hline $587 \mathrm{G}>\mathrm{A}$ & G196D & he7 & $\mathrm{r}$ & $(47) /(47)$ & NF & $\mathrm{N}$ (e-loop) & II & $?$ & NR \\
\hline $606 \mathrm{G}>\mathrm{T}$ & $\begin{array}{l}\text { W202C/ } \\
\text { splice }\end{array}$ & ho & $\mathrm{r}$ & $(116) /(116)$ & & Y (e-loop) & I & 4-8 wk & $\mathrm{dD}: \mathrm{NR}$ \\
\hline $\mathrm{c} 606+1 \mathrm{G}>\mathrm{A}$ & splice & he6;all.2 & $\mathrm{r}$ & $(90) /(90)$ & & (intr. 3) & I & 2 wk & $\mathrm{dD}: \mathrm{NR}$ \\
\hline $646 \mathrm{~T}>\mathrm{C}$ & S216P & he 1 , he 4 & $\mathrm{r}$ & $(33) /(31 ; 82)$ & $\mathrm{NF}$ & $\mathrm{N}($ tmd 6) & II & $3 \mathrm{mo}$ & $\mathrm{dD}: \mathrm{NR}$ \\
\hline $652 \mathrm{delC}$ & Frameshift & he6;all.1 & $\mathrm{r}$ & $(90) /(90)$ & & $\mathrm{N}(\operatorname{tmd} 6)$ & I & $2 \mathrm{wk}$ & $\mathrm{dD}: \mathrm{NR}$ \\
\hline 721delG & Frameshift & he & $\mathrm{d}$ & $(78) /(78)$ & $\mathrm{F}$ & $\mathrm{N}(\mathrm{C}$-tail) & IV & $12 \mathrm{mo}$ & ndD:NR; deh.: >300 \\
\hline 727delG & Frameshift & he & d & $(91) /(91)$ & $\mathrm{F}$ & N (C-tail) & IV & $?$ & dD:NR \\
\hline $761 \mathrm{G}>\mathrm{T}$ & $\mathrm{R} 254 \mathrm{~L}$ & he & d & $(29) /(29)$ & $\mathrm{F}$ & $\mathrm{N}$ (C-tail) & IV & $<12 \mathrm{mo}$ & ? \\
\hline 763-772del & Frameshift & he & d & $(78) /(78)$ & F & $\mathrm{N}$ (C-tail) & IV & $36 \mathrm{mo}$ & ndD:NR \\
\hline $772 \mathrm{G}>\mathrm{A}$ & $\mathrm{E} 258 \mathrm{~K}$ & he & $\mathrm{d}$ & $(103) /(103)$ & $\mathrm{F}$ & $\mathrm{N}$ (C-tail) & IV & $?$ & $\mathrm{dD}:>300$ \\
\hline $\begin{array}{l}\text { 779- } \\
\text { 780InsA }\end{array}$ & Frameshift & he & $\mathrm{d}$ & $(62) /(62)$ & $\mathrm{F}$ & N (C-tail) & IV & 6-1 mo & $\mathrm{dD}: \mathrm{NR}:>300$ \\
\hline
\end{tabular}

AQP2, aquaporin-2; he, Heterozygous; ho, homozygous; all, allele; r, recessive; d, dominant; NF, nonfunctional; P, partial functional (level in \% between brackets); conserved $(\mathrm{Y})$ or not $(\mathrm{N})$ between $\mathrm{AQP}$ proteins; $>300$, urine $>300 \mathrm{mosmol} / \mathrm{kgH}_{2} \mathrm{O}$.

sistent with their extensive degradation, AQP2 proteins could not be detected in the urine of patients with recessive NDI due to AQP2 gene mutations, in contrast to those of healthy controls or of a female V2R NDI patient $(32,65)$. Although ER retained, overexpression in oocytes, where a fraction of the AQP2 mutants are found in the plasma membrane, revealed that AQP2-L22V, -A47V, -G64R, -T125M, -T126M, -A147T, and $-\mathrm{V} 168 \mathrm{M}$ are functional as water channels on a molecular level $(23,90,92,104)$. Interestingly, AQP2-V168M yielded a less severe misfolding than other AQP2 mutants in NDI, which might explain the relatively mild form on NDI in a Mexican family encoding this mutant (20). In general, however, the urine concentrating ability of patients with recessive NDI due to AQP2 mutations are severely affected (urine osmolality $<100 \mathrm{mosmol} / \mathrm{kgH}_{2} \mathrm{O}$ ), indicating that in vivo plasma membrane expression of functional AQP2 mutants is negligible. The inability of these AQP2 mutants to form heterotetramers with wild-type AQP2 (wt-AQP2), leaving only the formation of wt-AQP2 homotetramers, likely explains the healthy phenotype of the parents (64). For this, an increased wt-AQP2 expression from the normal allele does not seem to be necessary, because the AQP2 heterozygote knockout mouse, which has a healthy phenotype, expresses about half of AQP2 found in normal mice (173).
Most mutations in autosomal recessive NDI are found in between the first and the last transmembrane domain (Table 2). As this segment forms the AQP2 water pore (105), the misfolding resulting from mutations in this part of the protein illustrates the sensitivity of the pore to structural changes. Recently, one mutation in recessive NDI was found outside this region. Surprisingly, this mutation encodes the P262L exchange in the AQP2 $\mathrm{COOH}$ tail, a location that was until then destined to result in dominant instead of recessive NDI (28). This mutation was found in two independent patients, encoding, besides AQP2-P262L, AQP2-A190T and AQPR187C mutants. Expression in oocytes revealed that the latter two mutants were ER retained (class II). The retention of AQP2-P262L in intracellular vesicles of polarized MDCK cells on stimulation with forskolin provided an explanation for its involvement in NDI, as in the patient neither AQP2-P262L nor AQP2-A190T/R187C would be expressed in the apical membrane of principal cells. However, the observed retention in a non-ER compartment was in still in line with a pattern encountered for AQP2 mutants in dominant NDI. Indeed, as found for mutants in dominant NDI, AQP2-P262L escaped the ER and formed heterotetramers with wt-AQP2, but not AQP2-A190T or AQP-R187C. On coexpression with wt-AQP2, however, wt-AQP2 appeared to target the wt-AQP2/AQP2-P262L com- 


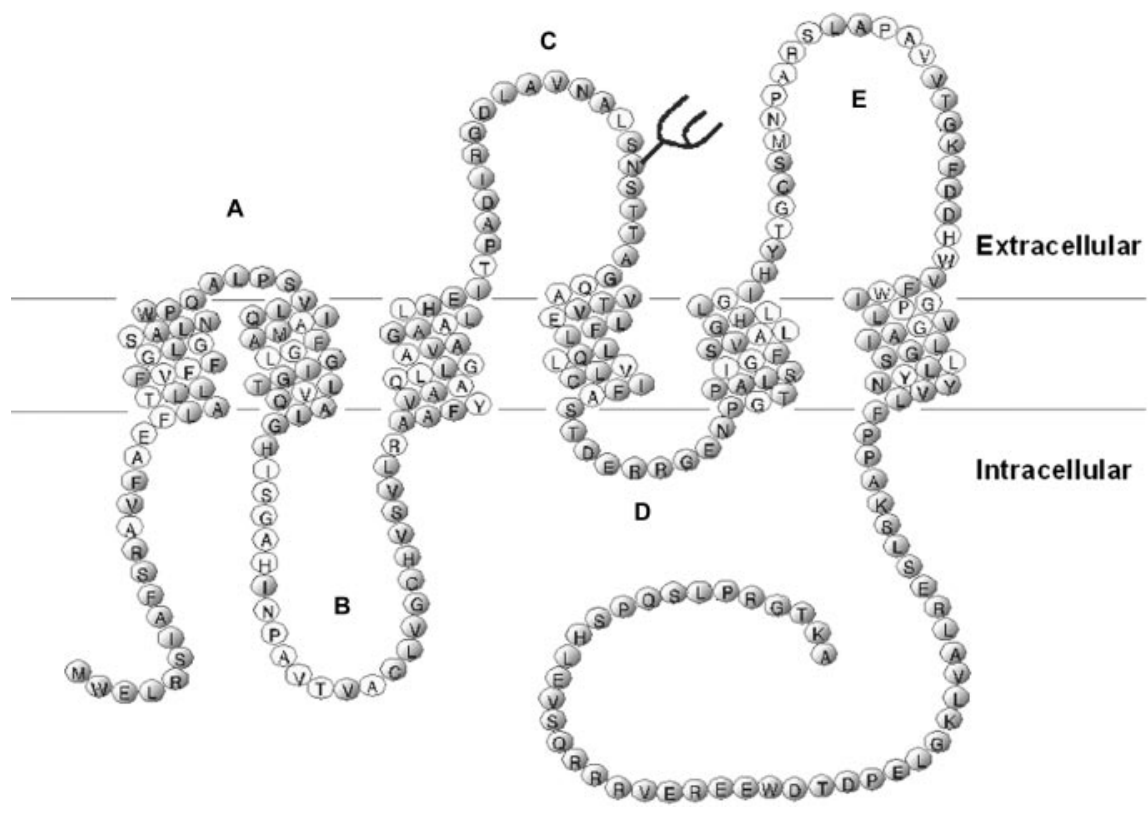

Fig. 4. Proposed topology of human AQP2. An AQP2 monomer consists of 6 transmembrane domains connected by 5 loops $(A-E)$ and its $\mathrm{NH}_{2}$ and $\mathrm{COOH}$ termini located intracellularly. Loops $B$ and $E$ meet each other with their characteristic NPA boxes in the membrane to form the water-selective pore. N-glycosylation (at N123) is indicated. Bright amino acids are conserved among different AQPs.

plexes to the apical membrane, indicating that, in contrast to AQP2 mutants in dominant NDI, the apical sorting signals of wt-AQP2 overrule the retention signals in AQP2-P262L, thereby explaining the involvement of AQP2-P262L in recessive instead of dominant NDI. The cellular phenotypes of patients in autosomal recessive and dominant NDI and their parents are summarized in Fig. 5.

\section{Autosomal Dominant NDI}

Being diagnosed in only seven families, autosomal dominant inheritance is the least prominent form of NDI. The mutations identified in these families comprise nucleotide deletion, insertion, as well as missense mutations (Table 2). By definition, these mutations are only found in one AQP2 allele. As waterselective AQPs are structurally similar and it was shown that, while expressed as homotetramers, an AQP1 monomer is the functional unit $(59,149,159)$, we reasoned that AQP2 mutants in dominant NDI should be able to interfere with the functioning of wt-AQP2. Indeed, on expression in oocytes, these AQP2 mutants were not ER retained and were able to form heterotetramers with wt-AQP2 (64). Due to the mutation, however, these molecularly functional AQP2 mutants were missorted (class $\mathrm{V}$ ) and, because of the formation of heterotetrameric complexes with wt-AQP2, also targeted wt-AQP2 to other subcellular destinations. Extrapolated to the principal cells of patients, this would lead to severely decreased amounts of AQP2 in the apical membrane, explaining the dominant mode of inheritance of NDI in their families (64).

Clinical analyses of patients with recessive and dominant NDI due to AQP2 mutations revealed three interesting differences $(62,78,91,103)$ (Table 2). First, the symptoms of NDI (polydipsia, polyuria) are already noticeable at birth in recessive NDI, whereas in dominant NDI they often become apparent in the second half of the first year or later. Second, urine osmolalities of patients with recessive NDI never exceed 200 mosmol/ $\mathrm{kgH}_{2} \mathrm{O}$, whereas those of dominant NDI are sometimes higher. Third, patients with dominant NDI sometimes show a transient increase in urine concentration shortly after
DDAVP administration or dehydration. This transient increase seems not to be related to the identified AQP2 mutation, because some patients in the AQP2-insA family did not respond. The observation that a dominant disease is subclinically "milder" than the recessive form is not restricted to NDI, because it is also found for long-QT syndrome, myotonia congenita, osteochondrodysplasias, and Robinow syndrome/ brachydactyly $(1,164,168,175)$.

Interestingly, all AQP2 mutations in dominant NDI are located in its $\mathrm{COOH}$ terminus (Figs. 4 and 5 and Table 2), which underscores the importance of this segment in trafficking of AQP2. Of the seven mutations described, six have shown or are likely to introduce a missorting signal. The first reported AQP2 mutant, AQP2-E258K, is missorted to the Golgi complex in oocytes, but to late endosomes/lysosomes in polarized cells $(52,103)$. This mutant is strongly retained in oocytes. Deletion of a small segment containing the E258K mutations greatly restored cell surface expression and water permeability, indicating that the introduced Lys instead of the loss of E258 caused the dominant feature (103). Although starting at different positions, all +1 frameshift mutations 721delG, 727delG, del763-772, and del812-818 resulted in a similarly extended COOH-terminal tail. In MDCK cells, AQP2-727delG localized to late endosomes/lysosomes, and to some extent the basolateral plasma membrane, whereas the other three mutants were present exclusively in the basolateral membrane $(7,78,91)$. The molecular signature causing the missorting of these AQP2 mutants has remained elusive. In contrast, an adenosine insertion at position 779 (insA) found in another patient yields a +2 reading frame shift, resulting in a different and slightly extended $\mathrm{COOH}$-terminal tail. Detailed analysis in MDCK cells revealed that this mutant was transported to the basolateral membrane, due to the introduction of two basolateral sorting signals in the changed $\mathrm{COOH}$-terminal segment (62).

Finally, one family with dominant NDI was found in which R254 was exchanged for a leucine (29). In contrast to the others, this mutation did not introduce a missorting signal, but 
Fig. 5. Cellular fate of AQP2 mutants in the different forms of autosomal recessive or dominant NDI. Shown is a schematic representation of a principal cell of the collecting duct of patients suffering from autosomal recessive NDI $(28,33)$ and their unaffected parents. For patients in autosomal dominant NDI, the carrier parent has a patient phenotype and is therefore not shown in this scheme. For details on the specific AQP2 mutants, see the text.

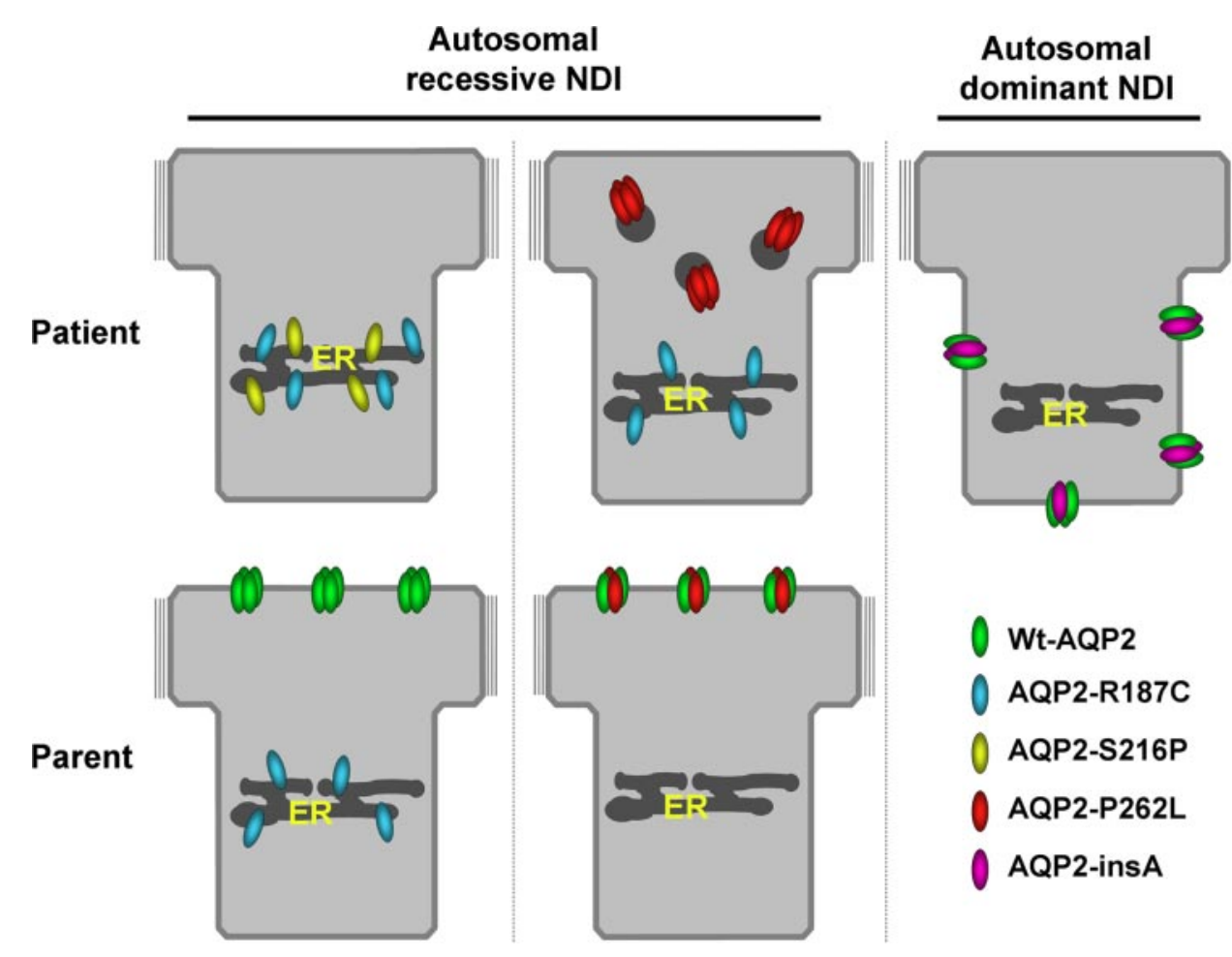

Autosomal recessive NDI interfered with S256 phosphorylation of AQP2 by PKA. Consequently, the formed wt-mutant complexes were retained in intracellular vesicles that are likely similar to the storage vesicles in which unstimulated wt-AQP2 accumulates. This was supported by the similar subcellular distribution of AQP2R254L, unstimulated wt-AQP2, and AQP2-S256A, which mimics nonphosphorylated AQP2, and their partial colocalization with the early endosome antigen-1 (EEA-1) marker protein.

\section{Genes in Nonhuman NDI}

To identify the physiological role or proteins, gene deletion by homologous recombination is often employed in mice. Using this knockout strategy, mice lacking AQP2 or the V2R appeared to suffer from severe NDI, resulting in perinatal death $(173,174)$. In contrast, mice lacking AQP3, SPA-1, Foxa1, CLC-K1, or all three nitric oxide synthase (NOS) isoforms, or expressing overactive PDE-III, showed milder forms of NDI $(12,76,86,93,101,106,111,156)$. While a role of AQP3 (exit of water from principal cells) ands PDE-III (reduced intracellular cAMP levels) in AVP-induced AQP2-mediated water transport is obvious, this is not so clear for the others. The signal-induced proliferation-associated gene-1 (SPA-1) protein, which is a GTPase-activating protein (GAP) for Rap1 containing a PDZ binding domain, directly bind AQP2 and has a role in its routing. However, its precise function in AQP2 trafficking now needs to be uncovered. Foxal is a member of the winged helix family of transcription factors and is expressed in the collecting ducts of the kidney. However, as the expression of the V2R and AQP2 are not affected, its molecular role is still unclear. As an increased interstitial tonicity is essential for water reabsorption, it would be interesting to determine whether the lack of Foxal reduces expression of renal salt transporters. The kidney-specific CLC-K1 chloride channel mediates transepithelial chloride transport in the thin ascending limb of Henle's loop (tAL) in the inner medulla and is involved in the generation and maintenance of the hypertonic medullary interstitium. While administration of DDAVP to these mice did not increase urine concentration, it is at present unclear whether this is only due to a reduced interstitial tonicity or also to reduced principal cell V2R or AQP2 expression. NDI in the triply nitric oxide synthase (NOS) knockout mice coincided with reduced membranous AQP2 expression associated with tubuloglomerular lesion formation and provide clear evidence of a critical role of the NOS system in maintaining renal homeostasis.

Although an occurrence of the loss of the three NOS proteins in humans is unlikely to be encountered, there is no report indicating that the lack of any of the above-mentioned genes causes NDI in humans. In fact, in nearly all our congenital NDI patients we have identified V2R or AQP2 gene mutations. Moreover, the discovery that humans lacking AQP3 are without any clinical phenotype (135) and that the lack of V2R or AQP2 is lethal in mice but not in humans seem to indicate that the urine concentrating mechanism is more sensitive in mice. Therefore, whereas the above-mentioned proteins might have a role in human renal osmoregulation, mutations in their genes are likely to lead to a subclinical phenotype in human water homeostasis or no phenotype at all.

\section{THERAPIES IN CONGENITAL NDI}

\section{Conventional Therapies}

The most important component of treatment for NDI is replacement of urinary water losses by adequate supply of fluid, in combination with a decreased solute diet to decrease obligatory water excretion. Diuretics such as hydrochlorothiazide and amiloride have been shown to effectively lower urine 
volume in NDI, which is, at least for hydrochlorothiazide, more pronounced in combination with a low-salt diet $(36,71)$. The combined administration of hydrochlorothiazide with either a prostaglandin synthesis [or cyclooxygenase (COX)] inhibitor such as indomethacin $\left(2 \mathrm{mg} \cdot \mathrm{kg}^{-1} \cdot \mathrm{day}^{-1}\right)$ or the potassium-sparing diuretic amiloride was shown to be much more effective in reducing urine volume than the thiazidediuretic alone $(4,58,73,74,97,127)$. Long-term use of prostaglandin-synthesis inhibitors, however, is often complicated by gastrointestinal and hematopoietic side effects. In addition, renal dysfunction has been described during indomethacin therapy, most often consisting of a reduction in GFR. Because of the known gastrointestinal safety of selective COX-2 inhibitors compared with nonselective COX inhibitors, a potential role for these drugs in the treatment of NDI has been put forward. In one male NDI infant, the effectiveness of a specific COX-2 inhibitor (rofecoxib) in decreasing urinary free water losses was indeed demonstrated (121). Nevertheless, in view of the recent discovery that prolonged use of that particular COX-2 inhibitor can cause severe cardiac side effects (148), we believe that COX-2 inhibitors should not be used in the treatment of NDI until it has been strictly determined which of these specific inhibitors are completely safe. However, while decreasing urine volume to a great extent, these treatments do not completely overcome the excess of water excretion, as adult patients with this conventional treatment still void 8-10 liters/day. Therefore, efforts into development of tailored therapies have been initiated.

\section{Tailored Therapies}

In general, renal gene therapy has been hampered by a low level of accessibility and the absence of selectivity of gene transfer techniques to and expression in particular renal cells $(54,79)$. In contrast, however, with the realization that success of pharmacotherapy depends on the cellular process disturbed by the disease-causing mutation, tailored pharmacotherapy has become highly promising:

\section{Antibiotics to Bypass Stop Codons}

A future therapy for patients harboring premature stop codon mutations (class I) is based on the ability of aminoglycoside antibiotics to cause translational read-through. Indeed, a gentamicin analog caused read-through of nonsense V2R mutants in vitro and in vivo $(143,147)$. However, the efficiency by which aminoglycosides confer read-through depends strongly on the nucleotides flanking the premature stop codon, and on the compound used, and some aminoglycosides exert toxic effects on the kidney, which severely limits their clinical use.

\section{ANP and the cGMP Pathway}

The paradigm for vasopressin signaling involves cAMPmediated PKA activation, which results in the functionally critical phosphorylation of AQP2 on S256 in vitro and in vivo $(29,45,63,68,157)$. As the AQP2 S256 phosphorylation site also fulfils the requirements for phosphorylation by cGMP kinase, Brown and co-workers $(21,22)$ came to the brilliant idea that the lack of cAMP generation in patients with X-linked NDI might be bypassed by pathways that activate cGMP kinase. Indeed, in an elegant study, they could show that acute elevation of cGMP levels by nitric oxide (NO), which thus plays an important role in renal water homeostasis (101), L-arginine, and atrial natriuretic peptide (ANP), led to AQP2 membrane insertion in both transfected cells and regions of the kidney collecting duct (21). This occurred without increasing intracellular cAMP levels and is thus independent of the V2R signaling pathway. Consistently, inhibitors of type 5 cGMP phosphodiesterases, like sildenafil, also induced the phosphorylation and plasma membrane translocation of AQP2 in these specimen (22). In vivo, chronic ANP infusion also induced an increased S256 phosphorylation and apical targeting of AQP2, but as ANP also induces natriuresis, it is at present unclear whether these effects are due to hypovolemia-induced increases in AVP release (167). It will be exciting to uncover whether ANP or other cGMP kinase-activating compounds will be beneficial for patients with X-linked NDI.

\section{"Pharmacological Chaperones" to Rescue V2R Mutants}

Very promising are also the approaches recently developed for class II V2R mutants. While their in vivo expression is likely low, transient overexpression of class II mutant proteins in oocytes or HEK293/COS cells, with which a small fraction are often expressed in the plasma membrane, allows the determination of whether such mutants are molecularly functional. Indeed, using such techniques, several (partially) ER-retained V2R and AQP2 mutants in NDI appeared to be functional at the molecular level, as the AQP2 mutants conferred water permeability, whereas the V2R mutants were able to mediate a cAMP response on stimulation with DDAVP $(23,90,92,104$, 124, 129, 170). In line with these findings, some patients harboring functional and partially ER-retained V2R mutants showed an increased urine concentration in response to high doses of AVP (95) (Table 1).

An important step forward in a putative treatment of these patients was the discovery that stabilization of mutant receptors by cell-permeable V2R antagonists, like SR121463B, aid in the mutant's folding, thereby facilitating their translocation to the plasma membrane $(99,153)$ (Fig. 3B). Because of their assistance in receptor folding, such cell-permeable ligands are termed pharmacological chaperones $(14,98)$. Although V2Rs with mutations at residues of major structural importance could not be rescued (e.g., H80R, W164R, S167L), the plasma membrane expression of most class II V2R mutants was restored (172). To be of therapeutic use, the rescuing antagonist has to be displaced by AVP after translocation of the V2R mutant to the basolateral membrane. As the competition between AVP and the rescuing ligand at the plasma membrane will determine functional rescue, low-affinity V2R ligands, like the V1R inverse agonist SR49059, are thought to be clinically more successful than high-affinity compounds such as SR121463B (15). Indeed, Bernier et al. (16) recently found that SR49059 showed a small, but significant, reduction in water intake and urine output in five NDI patients with missense V2R mutations, thus demonstrating the proof-of-principle that pharmacological chaperones can also rescue mutant V2R in vivo. Of great importance for this treatment, the relatively high blood levels of SR49059 came with a minimum of side effects, which is due to their high specificity for the V2R. As several other V1R and V2R antagonists have been developed and have been or are close to FDA approval, it will be exciting to find 
out to what extent they are able to relieve X-linked NDI caused by functional class II V2R mutants.

In conclusion, research on congenital NDI during the last 15 years has evolved from the identification of the genes involved and analysis of the cellular fate of the V2R and AQP2 mutants to the development of different strategies to bypass or overcome the inability of V2R mutants in X-linked NDI to mediate an antidiuretic response. While it is at present unclear whether a remedy for autosomal NDI can be developed, further development of the above-mentioned highly promising approaches and, especially, clinical testing of these separate or combined strategies in patients with X-linked NDI is anticipated to bring us an exciting scientific and clinical future, as it will tell us whether we can relieve or cure the major form of congenital NDI, 50 years after its first discovery (87).

\section{ACKNOWLEDGMENTS}

This work was supported by a grant from the Dutch Kidney Foundation (PC104) to P. M. T. Deen and N. V. A. M. Knoers.

\section{REFERENCES}

1. Afzal AR, Rajab A, Fenske CD, Oldridge M, Elanko N, TernesPereira E, Tuysuz B, Murday VA, Patton MA, Wilkie AO, and Jeffery S. Recessive Robinow syndrome, allelic to dominant brachydactyly type B, is caused by mutation of ROR2. Nat Genet 25: 419-422, 2000.

2. Ala Y, Morin D, Mouillac B, Sabatier N, Vargas R, Cotte N, Dechaux M, Antignac C, Arthus MF, Lonergan M, Turner MS, Balestre MN, Alonso G, Hibert M, Barberis C, Hendy GN, Bichet DG, and Jard S. Functional studies of twelve mutant V2 vasopressin receptors related to nephrogenic diabetes insipidus: molecular basis of a mild clinical phenotype. J Am Soc Nephrol 9: 1861-1872, 1998.

3. Albertazzi E, Zanchetta D, Barbier P, Faranda S, Frattini A, Vezzoni P, Procaccio M, Bettinelli A, Guzzi F, Parenti M, and Chini B. Nephrogenic diabetes insipidus: functional analysis of new AVPR2 mutations identified in Italian families. J Am Soc Nephrol 11: 1033-1043, 2000.

4. Alon $\mathbf{U}$ and Chan JC. Hydrochlorothiazide-amiloride in the treatment of congenital nephrogenic diabetes insipidus. Am J Nephrol 5: 9-13, 1985.

5. Andersen-Beckh B, Dehe M, Schulein R, Wiesner B, Rutz C, Liebenhoff $\mathbf{U}$, Rosenthal W, and Oksche A. Polarized expression of the vasopressin V2 receptor in Madin-Darby canine kidney cells. Kidney Int 56: 517-527, 1999.

6. Arthus MF, Lonergan M, Crumley MJ, Naumova AK, Morin D, De Marco LA, Kaplan BS, Robertson GL, Sasaki S, Morgan K, Bichet DG, and Fujiwara TM. Report of 33 novel AVPR2 mutations and analysis of 117 families with X-linked nephrogenic diabetes insipidus. J Am Soc Nephrol 11: 1044-1054, 2000.

7. Asai T, Kuwahara M, Kurihara H, Sakai T, Terada Y, Marumo F, and Sasaki S. Pathogenesis of nephrogenic diabetes insipidus by aquaporin-2 C-terminus mutations. Kidney Int 64: 2-10, 2003.

8. Bankir L, Fernandes S, Bardoux P, Bouby N, and Bichet DG. Vasopressin-v2 receptor stimulation reduces sodium excretion in healthy humans. J Am Soc Nephrol 16: 1920-1928, 2005.

9. Barak LS, Ferguson SSG, Zhang J, Martenson C, Meyer T, and Caron MG. Internal trafficking and surface mobility of a functionally intact $\beta_{2}$-adrenergic receptor-green fluorescent protein conjugate. Mol Pharmacol 51: 177-184, 1997.

10. Barak LS, Oakley RH, Laporte SA, and Caron MG. Constitutive arrestin-mediated desensitization of a human vasopressin receptor mutant associated with nephrogenic diabetes insipidus. Proc Natl Acad Sci USA 98: 93-98, 2001.

11. Baylis PH. The syndrome of inappropriate antidiuretic hormone secretion. Int J Biochem Cell Biol 35: 1495-1499, 2003.

12. Behr R, Brestelli J, Fulmer JT, Miyawaki N, Kleyman TR, and Kaestner KH. Mild nephrogenic diabetes insipidus caused by Foxa1 deficiency. J Biol Chem 279: 41936-41941, 2004.

13. Bendz H, Aurell M, and Lanke J. A historical cohort study of kidney damage in long-term lithium patients: continued surveillance needed. Eur Psychiatry 16: 199-206, 2001.
14. Bernier V, Lagace M, Bichet DG, and Bouvier M. Pharmacological chaperones: potential treatment for conformational diseases. Trends Endocrinol Metab 15: 222-228, 2004.

15. Bernier V, Lagace M, Lonergan M, Arthus MF, Bichet DG, and Bouvier M. Functional rescue of the constitutively internalized V2 vasopressin receptor mutant $\mathrm{R} 137 \mathrm{H}$ by the pharmacological chaperone action of SR49059. Mol Endocrinol 18: 2074-2084, 2004.

16. Bernier V, Morello JP, Zarruk A, Debrand N, Salahpour A, Lonergan M, Arthus MF, Laperriere A, Brouard R, Bouvier M, and Bichet DG. Pharmacologic chaperones as a potential treatment for X-linked nephrogenic diabetes insipidus. J Am Soc Nephrol 17: 232-243, 2006.

17. Bichet DG, Arthus MF, Lonergan M, Hendy GN, Paradis AJ, Fujiwara TM, Morgan K, Gregory MC, Rosenthal W, Didwania A, Antaramian A, and Birnbaumer M. $X$-linked nephrogenic diabetes insipidus mutations in North America and the Hopewell hypothesis. J Clin Invest 92: 1262-1268, 1993.

18. Bichet DG, Birnbaumer M, Lonergan M, Arthus MF, and Rosenthal W. Nature and recurrence of AVPR2 mutations in X-linked nephrogenic. Am J Hum Genet 55: 278-286, 1994.

19. Birnbaumer M, Seibold A, Gilbert S, Ishido M, Barberis C, Antaramian A, Brabet P, and Rosenthal W. Molecular-cloning of the receptor for human antidiuretic-hormone. Nature 357: 333-335, 1992.

20. Boccalandro C, De Mattia F, Guo DC, Xue L, Orlander P, King TM, Gupta P, Deen PMT, Lavis VR, and Milewicz DM. Characterization of an aquaporin-2 water channel gene mutation causing partial nephrogenic diabetes insipidus in a Mexican family: evidence of increased frequency of the mutation in the town of origin. J Am Soc Nephrol 15: 1223-1231, 2004.

21. Bouley R, Breton S, Sun T, McLaughlin M, Nsumu NN, Lin HY, Ausiello DA, and Brown D. Nitric oxide and atrial natriuretic factor stimulate cGMP-dependent membrane insertion of aquaporin 2 in renal epithelial cells. J Clin Invest 106: 1115-1126, 2000.

22. Bouley R, Pastor-Soler N, Cohen O, McLaughlin M, Breton S, and Brown D. Stimulation of AQP2 membrane insertion in renal epithelial cells in vitro and in vivo by the cGMP phosphodiesterase inhibitor sildenafil citrate (Viagra). Am J Physiol Renal Physiol 288: F1103F1112, 2005.

23. Canfield MC, Tamarappoo BK, Moses AM, Verkman AS, and Holtzman EJ. Identification and characterization of aquaporin-2 water channel mutations causing nephrogenic diabetes insipidus with partial vasopressin response. Hum Mol Genet 6: 1865-1871, 1997.

24. Chen CH, Chen WY, Liu HL, Liu TT, Tsou AP, Lin CY, Chao T, Qi $\mathbf{Y}$, and Hsiao KJ. Identification of mutations in the arginine vasopressin receptor 2 gene causing nephrogenic diabetes insipidus in Chinese patients. J Hum Genet 47: 66-73, 2002.

25. Christensen BM, Marples D, Kim YH, Wang W, Frøkiær J, and Nielsen S. Changes in cellular composition of kidney collecting duct cells in rats with lithium-induced NDI. Am J Physiol Cell Physiol 286: C952-C964, 2004.

26. Christensen S, Kusano E, Yusufi AN, Murayama N, and Dousa TP. Pathogenesis of nephrogenic diabetes insipidus due to chronic administration of lithium in rats. J Clin Invest 75: 1869-1879, 1985.

27. Cipriani A, Pretty H, Hawton K, and Geddes JR. Lithium in the prevention of suicidal behavior and all-cause mortality in patients with mood disorders: a systematic review of randomized trials. Am J Psychiatry 162: 1805-1819, 2005.

28. De Mattia F, Savelkoul PJ, Bichet DG, Kamsteeg EJ, Konings IB, Marr N, Arthus MF, Lonergan M, van Os CH, van der Sluijs P, Robertson G, and Deen PM. A novel mechanism in recessive nephrogenic diabetes insipidus: wild-type aquaporin-2 rescues the apical membrane expression of intracellularly retained AQP2-P262L. Hum Mol Genet 13: 3045-3056, 2004.

29. De Mattia F, Savelkoul PJ, Kamsteeg EJ, Konings IB, van der Sluijs P, Mallmann R, Oksche A, and Deen PM. Lack of arginine vasopressin-induced phosphorylation of aquaporin-2 mutant AQP2-R254L explains dominant nephrogenic diabetes insipidus. J Am Soc Nephrol 16: 2872-2880, 2005.

30. Deen PM and Brown D. Aquaporins: current topics in membranes. In: Trafficking of Native and Mutant Mammalian MIP Proteins, edited by Hohmann S, Agre P, and Nielsen S. San Diego, CA: Academic, 2001, p. 235-276.

31. Deen PM, Croes H, van Aubel RA, Ginsel LA, and van Os CH. Water channels encoded by mutant aquaporin-2 genes in nephrogenic diabetes 
insipidus are impaired in their cellular routing. J Clin Invest 95: 22912296, 1995.

32. Deen PM, van Aubel RA, van Lieburg AF, and van Os CH. Urinary content of aquaporin 1 and 2 in nephrogenic diabetes insipidus. J Am Soc Nephrol 7: 836-841, 1996.

33. Deen PM, Verdijk MAJ, Knoers NV, Wieringa B, Monnens LAH, van Os CH, and van Oost BA. Requirement of human renal water channel aquaporin-2 for vasopressin-dependent concentration of urine. Science 264: 92-95, 1994.

34. Deen PM, Weghuis DO, Sinke RJ, Geurts van Kessel A, Wieringa B, and van Os CH. Assignment of the human gene for the water channel of renal collecting duct aquaporin 2 (AQP2) to chromosome 12 region $\mathrm{q} 12 \rightarrow \mathrm{q} 13$. Cytogenet Cell Genet 66: 260-262, 1994.

35. DuBose TD Jr and Caflisch CR. Validation of the difference in urine and blood carbon dioxide tension during bicarbonate loading as an index of distal nephron acidification in experimental models of distal renal tubular acidosis. J Clin Invest 75: 1116-1123, 1985.

36. Earley LE, Kahn M, and Orloff J. The effects of infusions of chlorothiazide on urinary dilution and concentration in the dog. J Clin Invest 40: 857-866, 1961.

37. Earm JH, Christensen BM, Frøkiær J, Marples D, Han JS, Knepper MA, and Nielsen S. Decreased aquaporin-2 expression and apical plasma membrane delivery in kidney collecting ducts of polyuric hypercalcemic rats. J Am Soc Nephrol 9: 2181-2193, 1998.

38. Ecelbarger CA, Kim GH, Terris J, Masilamani S, Mitchell C, Reyes I, Verbalis JG, and Knepper MA. Vasopressin-mediated regulation of epithelial sodium channel abundance in rat kidney. Am J Physiol Renal Physiol 279: F46-F53, 2000.

39. Elkjaer ML, Kwon TH, Wang W, Nielsen J, Knepper MA, Frøkiær J, and Nielsen S. Altered expression of renal NHE3, TSC, BSC-1, and ENaC subunits in potassium-depleted rats. Am J Physiol Renal Physiol 283: F1376-F1388, 2002.

40. Ellgaard L and Helenius A. ER quality control: towards an understanding at the molecular level. Curr Opin Cell Biol 13: 431-437, 2001.

41. Frøkiær J, Christensen BM, Marples D, Djurhuus JC, Jensen UB, Knepper MA, and Nielsen S. Downregulation of aquaporin-2 parallels changes in renal water excretion in unilateral ureteral obstruction. Am J Physiol Renal Physiol 272: F213-F223, 1997.

42. Frøkiær J, Li C, Shi Y, Jensen A, Praetorius H, Hansen H, Topcu O, Sardeli C, Wang W, Kwon TH, and Nielsen S. Renal aquaporins and sodium transporters with special focus on urinary tract obstruction. APMIS Suppl: 71-79, 2003.

43. Frøkiær J, Marples D, Knepper MA, and Nielsen S. Bilateral ureteral obstruction downregulates expression of vasopressin-sensitive AQP-2 water channel in rat kidney. Am J Physiol Renal Fluid Electrolyte Physiol 270: F657-F668, 1996.

44. Fujiwara TM and Bichet DG. Molecular biology of hereditary diabetes insipidus. J Am Soc Nephrol 16: 2836-2846, 2005.

45. Fushimi K, Sasaki S, and Marumo F. Phosphorylation of serine 256 is required for cAMP-dependent regulatory exocytosis of the aquaporin-2 water channel. J Biol Chem 272: 14800-14804, 1997.

46. Goji K, Kuwahara M, Gu Y, Matsuo M, Marumo F, and Sasaki S. Novel mutations in aquaporin-2 gene in female siblings with nephrogenic diabetes insipidus: evidence of disrupted water channel function. J Clin Endocrinol Metab 83: 3205-3209, 1998.

47. Guyon C, Bissonnette P, Lussier Y, Arthus MF, Lonergan M, Bedoya Perez R, and Bichet D. Novel aquaporin-2 (AQP2) mutations responsible for autosomal recessive nephrogenic diabetes insipidus (Abstract). J Am Soc Nephrol 2004.

48. Hansen LK, Rittig S, and Robertson GL. Genetic basis of familial neurohypophyseal diabetes insipidus. Trends Endocrinol Metab 8: 363 372, 1997.

49. Hasler U, Mordasini D, Bens M, Bianchi M, Cluzeaud F, Rousselot M, Vandewalle A, Feraille E, and Martin PY. Long-term regulation of aquaporin-2 expression in vasopressin-responsive renal collecting duct principal cells. J Biol Chem 277: 10379-10386, 2002.

50. Hasler U, Vinciguerra M, Vandewalle A, Martin PY, and Feraille E. Dual effects of hypertonicity on aquaporin-2 expression in cultured renal collecting duct principal cells. J Am Soc Nephrol 16: 1571-1582, 2005.

51. Hermosilla R, Oueslati M, Donalies U, Schonenberger E, Krause E, Oksche A, Rosenthal W, and Schulein R. Disease-causing V vasopressin receptors are retained in different compartments of the early secretory pathway. Traffic 5: 993-1005, 2004.
52. Hirano K, Zuber C, Roth J, and Ziak M. The proteasome is involved in the degradation of different aquaporin-2 mutants causing nephrogenic diabetes insipidus. Am J Pathol 163: 111-120, 2003.

53. Hochberg Z, van Lieburg AF, Even L, Brenner B, Lanir N, van Oost BA, and Knoers NV. Autosomal recessive nephrogenic diabetes insipidus caused by an aquaporin-2 mutation. J Clin Endocrinol Metab 82: 686-689, 1997.

54. Imai E and Isaka Y. Gene therapy for kidney disease. Expert Opin Investig Drugs 9: 1029-1039, 2000.

55. Inaba $\mathbf{S}$, Hatakeyama $\mathbf{H}$, Taniguchi $\mathbf{N}$, and Miyamori I. The property of a novel v2 receptor mutant in a patient with nephrogenic diabetes insipidus. J Clin Endocrinol Metab 86: 381-385, 2001.

56. Innamorati G, Sadeghi H, Eberle AN, and Birnbaumer M. Phosphorylation of the V2 vasopressin receptor. J Biol Chem 272: 2486-2492, 1997.

57. Ishibashi K, Sasaki S, Fushimi K, Yamamoto T, Kuwahara M, and Marumo F. Immunolocalization and effect of dehydration on AQP3, a basolateral water channel of kidney collecting ducts. Am J Physiol Renal Physiol 272: F235-F241, 1997.

58. Jakobsson B and Berg U. Effect of hydrochlorothiazide and indomethacin treatment on renal function in nephrogenic diabetes insipidus. Acta Paediatr 83: 522-525, 1994.

59. Jung JS, Preston GM, Smith BL, Guggino WB, and Agre P. Molecular structure of the water channel through aquaporin CHIP. The hourglass model. J Biol Chem 269: 14648-14654, 1994.

60. Jung JY, Madsen KM, Han KH, Yang CW, Knepper MA, Sands JM, and Kim J. Expression of urea transporters in potassium-depleted mouse kidney. Am J Physiol Renal Physiol 285: F1210-F1224, 2003.

61. Kalenga K, Persu A, Goffin E, Lavenne-Pardonge E, van Cangh PJ, Bichet DG, and Devuyst $O$. Intrafamilial phenotype variability in nephrogenic diabetes insipidus. Am J Kidney Dis 39: 737-743, 2002.

62. Kamsteeg EJ, Bichet DG, Konings IB, Nivet H, Lonergan M, Arthus MF, van Os CH, and Deen PMT. Reversed polarized delivery of an aquaporin-2 mutant causes dominant nephrogenic diabetes insipidus. J Cell Biol 163: 1099-1109, 2003.

63. Kamsteeg EJ, Heijnen I, van Os CH, and Deen PM. The subcellular localization of an aquaporin-2 tetramer depends on the stoichiometry of phosphorylated and nonphosphorylated monomers. J Cell Biol 151: 919-930, 2000

64. Kamsteeg EJ, Wormhoudt TA, Rijss JPL, van Os CH, and Deen PM. An impaired routing of wild-type aquaporin-2 after tetramerization with an aquaporin-2 mutant explains dominant nephrogenic diabetes insipidus. EMBO J 18: 2394-2400, 1999.

65. Kanno K, Sasaki S, Hirata Y, Ishikawa S, Fushimi K, Nakanishi S, Bichet DG, and Marumo F. Urinary excretion of aquaporin-2 in patients with diabetes insipidus. N Engl J Med 332: 1540-1545, 1995.

66. Kasono K, Saito T, Saito T, Tamemoto H, Yanagidate C, Uchida S, Kawakami M, Sasaki S, and Ishikawa SE. Hypertonicity regulates the aquaporin-2 promoter independently of arginine vasopressin. Nephrol Dial Transplant 20: 509-515, 2005

67. Katsura T, Ausiello DA, and Brown D. Direct demonstration of aquaporin-2 water channel recycling in stably transfected LLC-PK epithelial cells. Am J Physiol Renal Fluid Electrolyte Physiol 270: F548-F553, 1996.

68. Katsura T, Gustafson CE, Ausiello DA, and Brown D. Protein kinase A phosphorylation is involved in regulated exocytosis of aquaporin-2 in transfected LLC-PK 1 cells. Am J Physiol Renal Physiol 272: F816-F822, 1997.

69. Kim SW, Gresz V, Rojek A, Wang W, Verkman AS, Frøkiær J, and Nielsen S. Decreased expression of AQP2 and AQP4 water channels and $\mathrm{Na}, \mathrm{K}-\mathrm{ATPase}$ in kidney collecting duct in AQP3 null mice. Biol Cell 97 . 765-778, 2005.

70. Kim YH, Kwon TH, Christensen BM, Nielsen J, Wall SM, Madsen KM, Frøkiær J, and Nielsen S. Altered expression of renal acid-base transporters in rats with lithium-induced NDI. Am J Physiol Renal Physiol 285: F1244-F1257, 2003.

71. Kirchlechner V, Koller DY, Seidl R, and Waldhauser F. Treatment of nephrogenic diabetes insipidus with hydrochlorothiazide and amiloride. Arch Dis Child 80: 548-552, 1999.

72. Knoers NV, van den Ouweland AM, Verdijk M, Monnens LA, and van Oost BA. Inheritance of mutations in the V2 receptor gene in thirteen families with nephrogenic diabetes insipidus. Kidney Int 46: 170-176, 1994 
73. Knoers N, Brommer EJ, Willems H, van Oost BA, and Monnens LA. Fibrinolytic responses to 1-desamino-8-D-arginine-vasopressin in patients with congenital nephrogenic diabetes insipidus. Nephron 54: 322 326, 1990 .

74. Konoshita T, Kuroda M, Kawane T, Koni I, Miyamori I, Tofuku Y, Mabuchi H, and Takeda R. Treatment of congenital nephrogenic diabetes insipidus with hydrochlorothiazide and amiloride in an adult patient. Horm Res 61: 63-67, 2004.

75. Kotnik P, Nielsen J, Kwon TH, Krzisnik C, Frøkiær J, and Nielsen S. Altered expression of COX-1, COX-2, and mPGES in rats with nephrogenic and central diabetes insipidus. Am J Physiol Renal Physiol 288: F1053-F1068, 2005.

76. Kusano E, Yusufi AN, Murayama N, Braun-Werness J, and Dousa TP. Dynamics of nucleotides in distal nephron of mice with nephrogenic diabetes insipidus. Am J Physiol Renal Fluid Electrolyte Physiol 250: F151-F158, 1986.

77. Kuwahara M. Aquaporin-2, a vasopressin-sensitive water channel, and nephrogenic diabetes insipidus. Intern Med 37: 215-217, 1998.

78. Kuwahara M, Iwai K, Ooeda T, Igarashi T, Ogawa E, Katsushima Y, Shinbo I, Uchida S, Terada Y, Arthus MF, Lonergan M, Fujiwara TM, Bichet DG, Marumo F, and Sasaki S. Three families with autosomal dominant nephrogenic diabetes insipidus caused by aquaporin-2 mutations in the C-terminus. Am J Hum Genet 69: 738-748, 2001.

79. Lai LW, Chan DM, Erickson RP, Hsu SJ, and Lien YH. Correction of renal tubular acidosis in carbonic anhydrase II-deficient mice with gene therapy. J Clin Invest 101: 1320-1325, 1998.

80. Laursen UH, Pihakaski-Maunsbach K, Kwon TH, Ostergaard JE, Nielsen S, and Maunsbach AB. Changes of rat kidney AQP2 and $\mathrm{Na}, \mathrm{K}-\mathrm{ATPase}$ mRNA expression in lithium-induced nephrogenic diabetes insipidus. Nephron Exp Nephrol 97: e1-e16, 2004.

81. Li C, Wang W, Kwon TH, Isikay L, Wen JG, Marples D, Djurhuus JC, Stockwell A, Knepper MA, Nielsen S, and Frøkiær J. Downregulation of AQP1, -2, and -3 after ureteral obstruction is associated with a long-term urine-concentrating defect. Am J Physiol Renal Physiol 281: F163-F171, 2001.

82. Li C, Wang W, Kwon TH, Knepper MA, Nielsen S, and Frøkiær J. Altered expression of major renal Na transporters in rats with unilateral ureteral obstruction. Am J Physiol Renal Physiol 284: F155-F166, 2003.

83. Li Y, Shaw S, Kamsteeg EJ, Vandewalle A, and Deen PM. Development of lithium-induced nephrogenic diabetes insipidus is dissociated from adenylyl cyclase activity. J Am Soc Nephrol. In press.

84. Lin SH, Bichet DG, Sasaki S, Kuwahara M, Arthus MF, Lonergan M, and Lin YF. Two novel aquaporin-2 mutations responsible for congenital nephrogenic diabetes insipidus in Chinese families. J Clin Endocrinol Metab 87: 2694-2700, 2002.

85. Lolait SJ, O'Carroll AM, McBride OW, Konig M, Morel A, and Brownstein MJ. Cloning and characterization of a vasopressin V2 receptor and possible link to nephrogenic diabetes-insipidus. Nature 357: 336-339, 1992.

86. Ma T, Song Y, Yang B, Gillespie A, Carlson EJ, Epstein CJ, and Verkman AS. Nephrogenic diabetes insipidus in mice lacking aquaporin-3 water channels. Proc Natl Acad Sci USA 97: 4386-4391, 2000.

87. MacDonald WB. Congenital nephrogenic diabetes insipidus. Med J Aust 40: 32-33, 1953.

88. Marples D, Christensen S, Christensen EI, Ottosen PD, and Nielsen S. Lithium-induced downregulation of aquaporin-2 water channel expression in rat kidney medulla. J Clin Invest 95: 1838-1845, 1995.

89. Marples D, Frøkiær J, Dorup J, Knepper MA, and Nielsen S. Hypokalemia-induced downregulation of aquaporin-2 water channel expression in rat kidney medulla and cortex. J Clin Invest 97: 1960-1968, 1996.

90. Marr N, Bichet DG, Hoefs S, Savelkoul PJ, Konings IB, De Mattia F, Graat MP, Arthus MF, Lonergan M, Fujiwara TM, Knoers NV, Landau D, Balfe WJ, Oksche A, Rosenthal W, Muller D, van Os CH, and Deen PM. Cell-biologic and functional analyses of five new aquaporin-2 missense mutations that cause recessive nephrogenic diabetes insipidus. J Am Soc Nephrol 13: 2267-2277, 2002.

91. Marr N, Bichet DG, Lonergan M, Arthus MF, Jeck N, Seyberth HW, Rosenthal W, van Os CH, Oksche A, and Deen PM. Heteroligomerization of an aquaporin-2 mutant with wild-type aquaporin-2 and their misrouting to late endosomes/lysosomes explains dominant nephrogenic diabetes insipidus. Hum Mol Genet 11: 779-789, 2002.
92. Marr N, Kamsteeg EJ, Van Raak M, van Os CH, and Deen PM. Functionality of aquaporin-2 missense mutants in recessive nephrogenic diabetes insipidus. Pflügers Arch 442: 73-77, 2001.

93. Matsumura Y, Uchida S, Kondo Y, Miyazaki H, Ko SB, Hayama A, Morimoto T, Liu W, Arisawa M, Sasaki S, and Marumo F. Overt nephrogenic diabetes insipidus in mice lacking the CLC-K1 chloride channel. Nat Genet 21: 95-98, 1999.

94. McKinley MJ and Johnson AK. The physiological regulation of thirst and fluid intake. News Physiol Sci 19: 1-6, 2004.

95. Mizuno H, Fujimoto S, Sugiyama Y, Kobayashi M, Ohro Y, Uchida S, Sasaki S, and Togari H. Successful treatment of partial nephrogenic diabetes insipidus with thiazide and desmopressin. Horm Res 59: $297-$ 300, 2003.

96. Mizuno H, Sugiyama Y, Ohro Y, Imamine H, Kobayashi M, Sasaki S, Uchida S, and Togari H. Clinical characteristics of eight patients with congenital nephrogenic diabetes insipidus. Endocrine 24: 55-59, 2004.

97. Monnens LAH, Jonkman A, and Thomas C. Response to indomethacin and hydrochlorothiazide in nephrogenic. Clin Sci (Colch) 66: 709$715,1984$.

98. Morello JP, Petaja-Repo UE, Bichet DG, and Bouvier M. Pharmacological chaperones: a new twist on receptor folding. Trends Pharmacol Sci 21: 466-469, 2000.

99. Morello JP, Salahpour A, Laperriere A, Bernier V, Arthus MF, Lonergan M, Petaja-Repo U, Angers S, Morin D, Bichet DG, and Bouvier M. Pharmacological chaperones rescue cell-surface expression and function of misfolded V2 vasopressin receptor mutants. J Clin Invest 105: 887-895, 2000

100. Morello JP, Salahpour A, Petaja-Repo UE, Laperriere A, Lonergan M, Arthus MF, Nabi IR, Bichet DG, and Bouvier M. Association of calnexin with wild type and mutant AVPR2 that causes nephrogenic diabetes insipidus. Biochemistry 40: 6766-6775, 2001.

101. Morishita T, Tsutsui M, Shimokawa H, Sabanai H, Tasaki H, Suda O, Nakata S, Tanimoto A, Wang KY, Ueta Y, Sasaguri Y, Nakashima Y, and Yanagihara N. Nephrogenic diabetes insipidus in mice lacking all nitric oxide synthase isoforms. Proc Natl Acad Sci USA 102: 10616-10621, 2005.

102. Moses AM, Scheinman SJ, and Oppenheim A. Marked hypotonic polyuria resulting from nephrogenic diabetes insipidus with partial sensitivity to vasopressin. J Clin Endocrinol Metab 59: 1044-1049, 1984.

103. Mulders SM, Bichet DG, Rijss JPL, Kamsteeg EJ, Arthus MF, Lonergan M, Fujiwara M, Morgan K, Leijendekker R, van der Sluijs P, van Os CH, and Deen PM. An aquaporin-2 water channel mutant which causes autosomal dominant nephrogenic diabetes insipidus is retained in the Golgi complex. J Clin Invest 102: 57-66, 1998.

104. Mulders SM, Knoers NV, van Lieburg AF, Monnens LAH, Leumann E, Wuhl E, Schober E, Rijss JPL, van Os CH, and Deen PM. New mutations in the AQP2 gene in nephrogenic diabetes insipidus resulting in functional but misrouted water channels. J Am Soc Nephrol 8: 242-248, 1997.

105. Murata K, Mitsuoka K, Hirai T, Walz T, Agre P, Heymann JB, Engel A, and Fujiyoshi Y. Structural determinants of water permeation through aquaporin-1. Nature 407: 599-605, 2000.

106. Naik DV. Salt and water metabolism and neurohypophyseal vasopressor activity in mice with hereditary nephrogenic diabetes insipidus. Acta Endocrinol (Copenh) 69: 434-444, 1972.

107. Nascimento L, Rademacher DR, Hamburger R, Arruda JA, and Kurtzman A. On the mechanism of lithium-induced renal tubular acidosis. J Lab Clin Med 89: 455-462, 1977.

108. Nielsen J, Kwon TH, Frøkiær J, Knepper MA, and Nielsen S. Lithium-induced NDI in rats is associated with loss of $\alpha-\mathrm{ENaC}$ regulation by aldosterone in CCD. Am J Physiol Renal Physiol 290: F1222F1233, 2006.

109. Nielsen J, Kwon TH, Praetorius J, Kim YH, Frøkiær J, Knepper $\mathbf{M A}$, and Nielsen S. Segment-specific ENaC downregulation in kidney of rats with lithium-induced NDI. Am J Physiol Renal Physiol 285: F1198-F1209, 2003.

110. Nielsen S, Frøkiær J, Marples D, Kwon TH, Agre P, and Knepper MA. Aquaporins in the kidney: from molecules to medicine. Physiol Rev 82: 205-244, 2002.

111. Noda Y, Horikawa S, Furukawa T, Hirai K, Katayama Y, Asai T, Kuwahara M, Katagiri K, Kinashi T, Hattori M, Minato N, and Sasaki S. Aquaporin-2 trafficking is regulated by PDZ-domain containing protein SPA-1. FEBS Lett 568: 139-145, 2004. 
112. Nonoguchi H, Owada A, Kobayashi N, Takayama M, Terada Y, Koike J, Ujiie K, Marumo F, Sakai T, and Tomita K. Immunohistochemical localization of V2 vasopressin receptor along the nephron and functional-role of luminal V2 receptor in terminal inner medullary collecting ducts. J Clin Invest 96: 1768-1778, 1995.

113. Norregaard R, Jensen BL, Li C, Wang W, Knepper MA, Nielsen S, and Frøkiær J. COX-2 inhibition prevents downregulation of key renal water and sodium transport proteins in response to bilateral ureteral obstruction. Am J Physiol Renal Physiol 289: F322-F333, 2005.

114. Oksche A, Dehe M, Schulein R, Wiesner B, and Rosenthal W. Folding and cell surface expression of the vasopressin V2 receptor: requirement of the intracellular C-terminus. FEBS Lett 424: 57-62, 1998.

115. Oksche A, Dickson J, Schulein R, Seyberth HW, and Muller M. Two novel mutations in the vasopressin V2 receptor gene in patients. Biochem Biophys Res Commun 205: 552-557, 1994.

116. Oksche A, Moller A, Dickson J, Rosendahl W, Rascher W, Bichet DG, and Rosenthal W. Two novel mutations in the aquaporin-2 and the vasopressin V2 receptor genes in patients with congenital nephrogenic diabetes insipidus. Hum Genet 98: 587-589, 1996.

117. Oksche A, Schulein R, Rutz C, Liebenhoff U, Dickson J, Muller H, Birnbaumer M, and Rosenthal W. Vasopressin V2 receptor mutants that cause X-linked nephrogenic diabetes insipidus: analysis of expression, processing, and function. Mol Pharmacol 50: 820-828, 1996.

118. Palmer BF. Hyponatremia in patients with central nervous system disease: SIADH versus CSW. Trends Endocrinol Metab 14: 182-187, 2003.

119. Pan Y, Wilson P, and Gitschier J. The effect of eight V2 vasopressin receptor mutations on stimulation. J Biol Chem 269: 31933-31937, 1994.

120. Pasel K, Schulz A, Timmermann K, Linnemann K, Hoeltzenbein M, Jaaskelainen J, Gruters A, Filler G, and Schoneberg T. Functiona characterization of the molecular defects causing nephrogenic diabetes insipidus in eight families. J Clin Endocrinol Metab 85: 1703-1710, 2000.

121. Pattaragarn A and Alon US. Treatment of congenital nephrogenic diabetes insipidus by hydrochlorothiazide and cyclooxygenase- 2 inhibitor. Pediatr Nephrol 18: 1073-1076, 2003.

122. Pedersen TS, Hvistendahl JJ, Djurhuus JC, and Frøkiær J. Renal water and sodium handling during gradated unilateral ureter obstruction. Scand J Urol Nephrol 36: 163-172, 2002.

123. Pollak MR. Disturbances of calcium metabolism. In: The Kidney, edited by Brenner BM. Philadelphia, PA: Saunders, 2000, p. 1037-1054.

124. Postina R, Ufer E, Pfeiffer R, Knoers NV, and Fahrenholz F. Misfolded vasopressin V2 receptors caused by extracellular point mutations entail congenital nephrogenic diabetes insipidus. Mol Cell Endocrinol 164: 31-39, 2000

125. Procino G, Carmosino M, Tamma G, Gouraud S, Laera A, Riccardi D, Svelto M, and Valenti G. Extracellular calcium antagonizes forskolin-induced aquaporin 2 trafficking in collecting duct cells. Kidney Int 66 2245-2255, 2004.

126. Rao R, Zhang MZ, Zhao M, Cai H, Harris RC, Breyer MD, and Hao CM. Lithium treatment inhibits renal GSK-3 activity and promotes cyclooxygenase 2-dependent polyuria. Am J Physiol Renal Physiol 288: F642-F649, 2005.

127. Rascher W, Rosendahl W, Henrichs IA, Maier R, and Seyberth HW. Congenital nephrogenic diabetes insipidus-vasopressin and prostaglandins in response to treatment with hydrochlorothiazide and indomethacin. Pediatr Nephrol 1: 485-490, 1987.

128. Rittig S, Siggaard C, Ozata M, Yetkin I, Gregersen N, Pedersen EB, and Robertson GL. Autosomal dominant neurohypophyseal diabetes insipidus due to substitution of histidine for tyrosine(2) in the vasopressin moiety of the hormone precursor. J Clin Endocrinol Metab 87: 3351 3355,2002

129. Robben JH, Knoers NV, and Deen PM. Characterization of vasopressin V2 receptor mutants in nephrogenic diabetes insipidus in a polarized cell model. Am J Physiol Renal Physiol 289: F265-F272, 2005.

130. Rocha JL, Friedman E, Boson W, Moreira A, Figueiredo B, Liberman B, de Lacerda L, Sandrini R, Graf H, Martins S, Punales MK, and De Marco L. Molecular analyses of the vasopressin type 2 receptor and aquaporin-2 genes in Brazilian kindreds with nephrogenic diabetes insipidus. Hum Mutat 14: 233-239, 1999.

131. Rojek A, Nielsen J, Brooks HL, Gong H, Kim YH, Kwon TH, Frøkiær J, and Nielsen S. Altered expression of selected genes in kidney of rats with lithium-induced NDI. Am J Physiol Renal Physiol 288: F1276-F1289, 2005
132. Roscoe JM, Goldstein MB, Halperin ML, Wilson DR, and Stinebaugh BJ. Lithium-induced impairment of urine acidification. Kidney Int 9: 344-350, 1976 .

133. Rosenthal W, Antaramian A, Gilbert S, and Birnbaumer M. Nephrogenic diabetes insipidus. A V2 vasopressin receptor unable to stimulate adenylyl cyclase. J Biol Chem 268: 13030-13033, 1993.

134. Rosenthal W, Seibold A, Antaramian A, Gilbert S, Birnbaumer M, Bichet DG, Arthus MF, and Lonergan M. Mutations in the vasopressin V2 receptor gene in families with nephrogenic diabetes insipidus and functional expression of the Q-2 mutant. Cell Mol Biol (Noisy-le-grand) 40: 429-436, 1994.

135. Roudier N, Ripoche P, Gane P, Le Pennec PY, Daniels G, Cartron JP, and Bailly P. AQP3 deficiency in humans and the molecular basis of a novel blood group system, GIL. J Biol Chem 277: 45854-45859, 2002.

136. Sadeghi H, Robertson GL, Bichet DG, Innamorati G, and Birnbaumer M. Biochemical basis of partial nephrogenic diabetes insipidus phenotypes. Mol Endocrinol 11: 1806-1813, 1997.

137. Sadeghi HM, Innamorati G, and Birnbaumer M. An X-linked NDI mutation reveals a requirement for cell surface V2R expression. Mol Endocrinol 11: 706-713, 1997.

138. Sadeghi HM, Innamorati G, and Birnbaumer M. Maturation of receptor proteins in eukaryotic expression systems. J Recept Signal Transduct Res 17: 433-445, 1997

139. Sadeghi HM, Innamorati G, Esqueda E, and Birnbaumer M. Processing and ligand-induced modifications of the V2 vasopressin receptor. Adv Exp Med Biol 449: 339-346, 1998

140. Saito F, Sasaki S, Chepelinsky AB, Fushimi K, Marumo F, and Ikeuchi T. Human AQP2 and MIP genes, two members of the MIP family, map within chromosome band $12 \mathrm{q} 13$ on the basis of two-color FISH. Cytogenet Cell Genet 68: 45-48, 1995.

141. Sands JM. Molecular mechanisms of urea transport. J Membr Biol 191: $149-163,2003$

142. Sands JM, Naruse M, Baum M, Jo I, Hebert SC, Brown EM, and Harris HW. Apical extracellular calcium/polyvalent cation-sensing receptor regulates vasopressin-elicited water permeability in rat kidney inner medullary collecting duct. J Clin Invest 99: 1399-1405, 1997.

143. Sangkuhl K, Schulz A, Rompler H, Yun J, Wess J, and Schoneberg T. Aminoglycoside-mediated rescue of a disease-causing nonsense mutation in the V2 vasopressin receptor gene in vitro and in vivo. Hum Mol Genet 13: 893-903, 2004.

144. Schoneberg T, Schulz A, Biebermann H, Gruters A, Grimm T, Hubschmann K, Filler G, Gudermann T, and Schultz G. V2 vasopressin receptor dysfunction in nephrogenic diabetes insipidus caused by different molecular mechanisms. Hum Mutat 12: 196-205, 1998.

145. Schulein R, Zuhlke K, Krause G, and Rosenthal W. Functional rescue of the nephrogenic diabetes insipidus-causing vasopressin V2 receptor mutants $\mathrm{G} 185 \mathrm{C}$ and $\mathrm{R} 202 \mathrm{C}$ by a second site suppressor mutation. J Biol Chem 276: 8384-8392, 2001.

146. Schulz A, Grosse R, Schultz G, Gudermann T, and Schoneberg T. Structural implication for receptor oligomerization from functional reconstitution studies of mutant V2 vasopressin receptors. J Biol Chem 275: 2381-2389, 2000

147. Schulz A, Sangkuhl K, Lennert T, Wigger M, Price DA, Nuuja A, Gruters A, Schultz G, and Schoneberg T. Aminoglycoside pretreatment partially restores the function of truncated V2 vasopressin receptors found in patients with nephrogenic diabetes insipidus. J Clin Endocrinol Metab 87: 5247-5257, 2002.

148. Singh D. Merck withdraws arthritis drug worldwide. BMJ 329: 816, 2004.

149. Smith BL and Agre P. Erythrocyte $M_{\mathrm{r}} 28,000$ transmembrane protein exists as a multisubunit oligomer similar to channel proteins. J Biol Chem 266: 6407-6415, 1991 .

150. Stone KA. Lithium-induced nephrogenic diabetes insipidus. J Am Board Fam Pract 12: 43-47, 1999.

151. Storm R, Klussmann E, Geelhaar A, Rosenthal W, and Maric K. Osmolality and solute composition are strong regulators of AQP2 expression in renal principal cells. Am J Physiol Renal Physiol 284: F189-F198, 2003.

152. Tamarappoo BK and Verkman AS. Defective aquaporin-2 trafficking in nephrogenic diabetes insipidus and correction by chemical chaperones. J Clin Invest 101: 2257-2267, 1998.

153. Tan CM, Nickols HH, and Limbird LE. Appropriate polarization following pharmacological rescue of $\mathrm{V} 2$ vasopressin receptors encoded by X-linked nephrogenic diabetes insipidus alleles involves a conforma- 
tion of the receptor that also attains mature glycosylation. $J$ Biol Chem 278: 35678-35686, 2003.

154. Tfelt-Hansen $\mathbf{J}$ and Brown EM. The calcium-sensing receptor in normal physiology and pathophysiology: a review. Crit Rev Clin Lab Sci 42: 35-70, 2005 .

155. Tsukaguchi $\mathbf{H}$, Matsubara $\mathbf{H}$, Taketani S, Mori $\mathbf{Y}$, Seido $\mathbf{T}$, and Inada M. Binding-, intracellular transport-, and biosynthesis-defective mutants of vasopressin type 2 receptor in patients with X-linked nephrogenic diabetes insipidus. $J$ Clin Invest 96: 2043-2050, 1995.

156. Valtin H, Coffey AK, O'Sullivan DJ, Homma S, and Dousa TP. Causes of the urinary concentrating defect in mice with nephrogenic diabetes insipidus. Physiol Bohemoslov 39: 103-111, 1990.

157. Van Balkom BWM, Savelkoul PJ, Markovich D, Hofman E, Nielsen S, van der Sluijs P, and Deen PMT. The role of putative phosphorylation sites in the targeting and shuttling of the aquaporin-2 water channel. J Biol Chem 277: 41473-41479, 2002.

158. Van den Ouweland AM, Dreesen JC, Verdijk MAJ, and Knoers NV. Mutations in the vasopressin type 2 receptor gene (AVPR2) associated with nephrogenic diabetes insipidus. Nat Genet 2: 99-102, 1992.

159. Van Hoek AN, Luthjens LH, Hom ML, van Os CH, and Dempster JA. A $30 \mathrm{kDa}$ functional size for the erythrocyte water channel determined in situ by radiation inactivation. Biochem Biophys Res Commun 184: 1331-1338, 1992.

160. Van Lieburg AF, Knoers NV, and Monnens LA. Clinical presentation and follow-up of 30 patients with congenital nephrogenic diabetes insipidus. J Am Soc Nephrol 10: 1958-1964, 1999.

161. Van Lieburg AF, Verdijk MAJ, Knoers NV, Afer E, Pastina R, Fahrenholz F, and van Oost BA. In vitro expression of mutations in the V2 receptor gene-confirmation of their role in the pathogenesis of X-linked nephrogenic diabetes insipidus. Pediatr Nephrol 8: c75, 1994

162. Van Lieburg AF, Verdijk MAJ, Knoers NV, van Essen AJ, Proesmans W, Mallmann R, Monnens LAH, van Oost BA, van Os CH, and Deen PM. Patients with autosomal nephrogenic diabetes insipidus homozygous for mutations in the aquaporin 2 water-channel gene. Am J Hum Genet 55: 648-652, 1994.

163. Vargas-Poussou R, Forestier L, Dautzenberg MD, Niaudet P, Dechaux M, and Antignac C. Mutations in the vasopressin V2 receptor and aquaporin-2 genes in twelve families with congenital nephrogenic diabetes insipidus. Adv Exp Med Biol 449: 387-390, 1998.

164. Vikkula M, Mariman EC, Lui VC, Zhidkova NI, Tiller GE, Goldring MB, van Beersum SE, de Waal Malefijt MC, van den Hoogen FH, Ropers HH, Mayne R, Cheah KS, Olson BR, Warman ML, and Brunner HG. Autosomal dominant and recessive osteochondrodysplasias associated with the COL11A2 locus. Cell 80: 431-437, 1995.
165. Wang W, Li C, Kwon TH, Knepper MA, Frøkiær J, and Nielsen S. $\mathrm{AQP} 3, \mathrm{p}-\mathrm{AQP} 2$, and AQP2 expression is reduced in polyuric rats with hypercalcemia: prevention by cAMP-PDE inhibitors. Am J Physiol Renal Physiol 283: F1313-F1325, 2002.

166. Wang W, Li C, Kwon TH, Miller RT, Knepper MA, Frøkiær J, and Nielsen S. Reduced expression of renal $\mathrm{Na}^{+}$transporters in rats with PTH-induced hypercalcemia. Am J Physiol Renal Physiol 286: F534F545, 2004.

167. Wang W, Li C, Nejsum LN, Li H, Kim SW, Kwon TH, Jonassen TE, Knepper MA, Thomsen K, Frøkiær J, and Nielsen S. Biphasic effects of ANP infusion in conscious, euvolumic rats: roles of AQP2 and ENaC trafficking. Am J Physiol Renal Physiol 290: F530-F541, 2006.

168. Wei J, Fish FA, Myerburg RJ, Roden DM, and George AL Jr. Novel KCNQ1 mutations associated with recessive and dominant congenital long QT syndromes: evidence for variable hearing phenotype associated with R518X. Hum Mutat 15: 387-388, 2000.

169. Wenkert D, Schoneberg T, Merendino JJ, Pena MSR, Vinitsky R, Goldsmith PK, Wess J, and Spiegel AM. Functional characterization of five V2 vasopressin receptor gene mutations. Mol Cell Endocrinol 124: 43-50, 1996.

170. Wildin RS, Cogdell DE, and Valadez V. AVPR2 variants and V2 vasopressin receptor function in nephrogenic diabetes insipidus. Kidney Int 54: 1909-1922, 1998.

171. Wingo CS and Weiner ID. Disorders of potassium balance. In: The Kidney, edited by Brenner BM. Philadelphia, PA: Saunders, 2000, p. 998-1035.

172. Wuller S, Wiesner B, Loffler A, Furkert J, Krause G, Hermosilla R, Schaefer M, Schulein R, Rosenthal W, and Oksche A. Pharmacochaperones post-translationally enhance cell surface expression by increasing conformational stability of wild-type and mutant vasopressin V2 receptors. J Biol Chem 279: 47254-47263, 2004.

173. Yang B, Gillespie A, Carlson EJ, Epstein CJ, and Verkman AS. Neonatal mortality in an aquaporin-2 knock-in mouse model of recessive nephrogenic diabetes insipidus. J Biol Chem 276: 2775-2779, 2000.

174. Yun J, Schoneberg T, Liu J, Schulz A, Ecelbarger CA, Promeneur D, Nielsen S, Sheng H, Grinberg A, Deng C, and Wess J. Generation and phenotype of mice harboring a nonsense mutation in the $\mathrm{V} 2$ vasopressin receptor gene. J Clin Invest 106: 1361-1371, 2000.

175. Zhang J, George AL Jr, Griggs RC, Fouad GT, Roberts J, Kwiecinski H, Connolly AM and Ptacek LJ. Mutations in the human skeletal muscle chloride channel gene (CLCN1) associated with dominant and recessive myotonia congenita. Neurology 47: 993-998, 1996. 